\title{
Novel methodological approaches in loess research - interrogating biomarkers and compound-specific stable isotopes
}

\author{
Michael Zech, Roland Zech, Björn Buggle, Ludwig Zöller
}

Abstract:

\begin{abstract}
Loess-paleosol sequences are unique terrestrial archives for the reconstruction of Quaternary landscape and climate history. The development of novel, more quantitative paleoclimate proxies may initiate a new era of loess research over the next decade. This review paper presents the principles, analytical backgrounds, and first applications of some of these new proxies that are currently being developed. We discuss the potential of (i) n-alkanes as plant leaf wax-derived biomarkers for reconstructing vegetation history, (ii) amino acid racemization and glycerol dialkyl glycerol tetraether (GDGT) indices as proxies for reconstructing paleotemperature and (iii) compound-specific $\delta \mathrm{D}$ and $\delta^{18} \mathrm{O}$ analyzes of plant-derived $\mathrm{n}$-alkanes and monosaccharides, respectively, as proxies for reconstructing paleoclimate/-aridity. While we want to inspire the readership about the exciting methodological and analytical developments and their potential for loess research, the current limitations and shortcomings of each proxy should not be overlooked. Degradation effects and possible post-depositional'contamination', for example, need to be considered when interpreting biomarker records, and the deconvolution of varying factors influencing the isotopic signals can be challenging.
\end{abstract}

[Neue methodische Ansätze in der Lössforschung - Biomarker- und substanzspezifische Stabilisotopen-Analytik]

Kurzfassung:

Löss-Paläoboden Sequenzen sind wichtige terrestrische Archive für die Rekonstruktion der quartären Landschafts- und Klimageschichte. Die Entwicklung neuer, quantitativerer Paläoklima-Proxies könnte in den kommenden Jahren eine neue Ära in der Lössforschung einleiten. Dieser Review-Artikel stellt die Prinzipien, die zugrunde liegende Analytik, und erste Anwendungsbeispiele für einige dieser Proxies vor, welche derzeit entwickelt werden. Wir diskutieren das Potential von (i) pflanzenwachsbürtigen n-Alkanen als Biomarker für die Rekonstruktion der Vegetationsgeschichte, (ii) Aminosäure Razemisierung und Glycerin-DialkylGlycerin-Tetraether (GDGT) Indizes als Proxies für die Rekonstruktion der Paläotemperatur und (iii) substanzspezifischen $\delta$ D and $\delta^{18} \mathrm{O}$ Analysen an pflanzenbürtigen n-Alkanen bzw. Zuckern für die Entwicklung von Proxies zur Rekonstruktion von Paläoklima/aridität. Während wir versuchen, die Leserschaft für die methodischen und analytischen Neuentwicklungen und deren Potential für die Lössforschung zu begeistern, verweisen wir gleichzeitig auch auf die Limitierungen und Schwächen der jeweiligen Methoden. So müssen beispielsweise Degradationseffekte oder postsedimentäre ,Kontamination' bei der Interpretation von Biomarker-Rekords berücksichtigt und weiter untersucht werden. Des Weiteren könnte sich die Quantifizierung der unterschiedlichen Einflussfaktoren auf Deuterium- und ${ }^{18} \mathrm{O}$-Rekords als herausfordernd erweisen.

Keywords: $\quad$ Loess, paleoenvironment, paleoclimate, biomarker, molecular fossil, n-alkane, glycerol dialkyl glycerol tetraether, amino acid racemization, sugar, stable isotope, $\delta D, \delta^{18} O$

Addresses of authors: M. Zech*, , L. Zöller, Chair of Geomorphology, University of Bayreuth, Universitätsstr. 30, 95440 Bayreuth, Germany. E-Mail michael_zech@gmx.de; M. Zech, B. Buggle, Department of Soil Physics, University of Bayreuth, Universitätsstr. 30, 95440 Bayreuth, Germany. M. Zech, B. Buggle, Department of Terrestrial Biogeochemistry, Martin-Luther University Halle-Wittenberg, Weidenplan 14, D-06120 Halle, Germany. R. Zech*, Geological Institute, Brown University, 324 Brook Street, Providence RI 02912, USA. R. Zech now at: Geological Institute, ETH Zurich, Sonneggstr. 5, 8092 Zurich, Switzerland. "these authors contributed equally to this manuscript. * corresponding author

\section{Introduction}

Ocean sediments and polar ice cores have provided invaluable insights into the climate system, its natural variability, forcings and mechanisms over the last few decades. However, it is the terrestrial, non-polar regions that provide most of the ecosystem services that we depend on. In view of global warming and the anticipated negative effects for ecosystems and economies, increasing scientific efforts should focus on reconstructing past climate and environmental conditions on land. We need a profound understanding of climate change-induced geomorphological processes and ecological consequences.

Loess-paleosol sequences (LPS) are unique terrestrial archives for this purpose. Most famous from the Chinese Loess
Plateau, LPS have also accumulated tens to hundreds of meters at places in Europe, Siberia, Alaska and South America (MARKovic et al. 2009; ZÖlLER \& FAUST 2009; FreCHEN 2011). The typical succession of loess and paleosols generally reflects glacial and interglacial periods, respectively, and thus the characteristic climate variability of the Quaternary, the last 2.6 Ma. The international 'Loessfest 2009' (MARKovic 2011) in Novi Sad, Serbia, recently provided a platform for presenting scientific results, for discussing new methodological developments, and strengthening the international cooperation in loess research. An overview over the progresses made during the last decade is provided in Zöller (2010). Emphasis therein was mainly put on the developments of the dating methods, as well as on high-resolution magnetic susceptibility and grain-size measurements, because these 
allow detailed reconstructions of pedogenesis and wind strength.

The aim of this review is to elaborate further on the most recent proxy developments. Our motivation stems from the anticipation that sophisticated analytical equipment, including HPLC (high performance liquid chromatography) and GC-IRMS (gas chromatography - isotope ratio mass spectrometry), will become more widely available and boost loess research over the next decade. The new tools will provide valuable, complementary paleoclimate and paleoenvironmental proxies. In this review, we can only give an overview over the principles of the proxies that we are currently working on, so by no means it should be considered to cover the full range of interesting, promising, new methods. The potential, as well as the current limitations of the presented methods will be illustrated in selected case studies.

\section{Biomarkers and compound-specific stable isotope analyzes [CSIA] - some basics}

Biomarkers are organic molecules that are produced by certain organisms or groups of organisms and thus have more or less specific sources. In many cases, they serve essential biophysiological functions, for example as membrane lipids in soil-thriving bacteria, or as leaf waxes for plants. Provided that the biomarkers are sufficiently resis-tant to degradation and mineralization, they are preserved in soils and can be extracted and analyzed in paleosols to reconstruct past changes in vegetation or bacterial communities. Biomarkers can thus be considered as molecular fossils (EGANHOUSE 1997; EGLINTON \& EGLINTON 2008).
The analytical determination of biomarkers generally starts with an (i) extraction or hydrolysis step. For example, lipid biomarkers are extracted from soil/sediment samples with organic solvents traditionally using Soxhlet apparatuses and biomarkers that form macromolecules such as aminoacids (in proteins) or sugars (in polysaccharides) are hydrolytically released using acids. (ii) Subsequently, there commonly follow various purification steps e.g. to remove interfering cations. (iii) Quantification of the individual molecules is in many cases carried out via gas chromatography (GC) coupled to flame ionisation detectors (FID) or to mass spectrometers (MS). Frequently, molecules have to be derivatised to be measurable via GC because they are low-volatile or not volatile at all. For instance, transformation of hydroxyl groups into trimethylsilyl-(TMS-)derivatives using e.g. N,O-Bis(trimethysilyl)fluoroacetamid (BSTFA) increases the volatileness of molecules by disabling hydrogen bonds. But as HPLC becomes more common and available, this step is not necessary any more for those biomarkers that can be measured via HPLC.

Concerning stable isotopes, $\delta^{13} \mathrm{C}$ and $\delta^{15} \mathrm{~N}$ analyzes of bulk samples, for instance of soil or sediments samples, can be accomplished relatively easy via elemental analysis - isotope ratio mass spectrometry (EA-IRMS). Carbon and nitrogen of samples are thereby transformed into carbon dioxide $\left(\mathrm{CO}_{2}\right)$ and nitrogen $\left(\mathrm{N}_{2}\right)$, respectively, in the EA. Subsequently, the abundance of heavy versus light isotopes $\left({ }^{13} \mathrm{C} /{ }^{12} \mathrm{C}\right.$ and ${ }^{15} \mathrm{~N} /{ }^{14} \mathrm{~N}$, respectively) in these gases is directly determined online in the coupled IRMS. Hence, these analyzes are meanwhile well established in many different scientific communities and allow, for example, reconstructing C3-C4 vegetation changes (BoutTon 1996; LiU et al. 2005; ZECH et

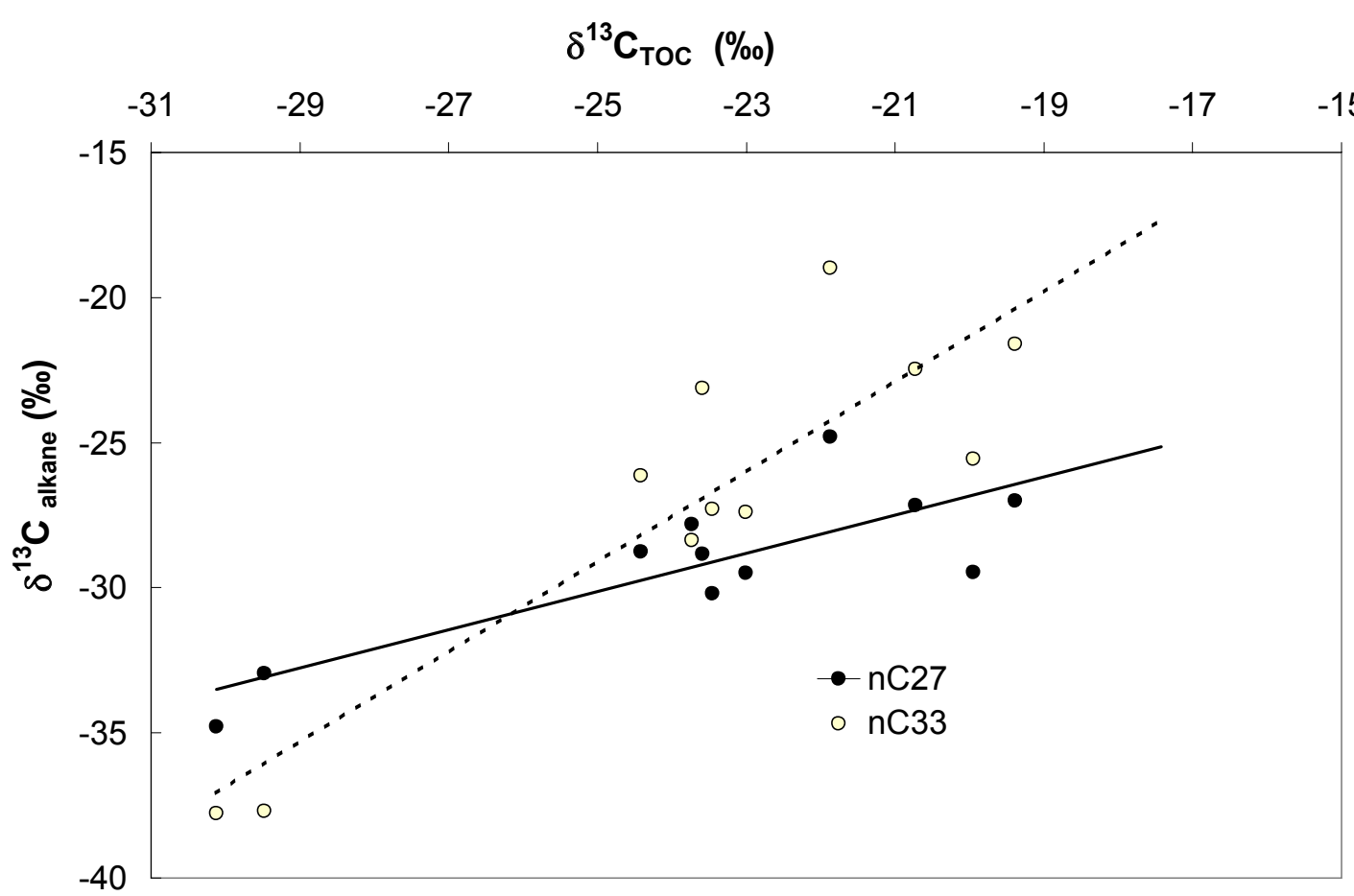

Fig. 1: Correlation of compound-specific $\delta^{13} \mathrm{C}$ (shown here are $n C_{27}$ and $n C_{33}$ ) with bulk $\delta^{13} \mathrm{C}$ (on total organic carbon, TOC) in a sediment core from Argentina (ZECH et al. 2009b). The higher amplitude for $\delta^{13} \mathrm{C}$ of $n C_{33}$ compared to $\delta^{13} \mathrm{C}$ of $n C_{27}$ reflects the dominant origin of $n C_{33}$ from $C 3$ - or $C 4$-grasses, whereas $n C_{27}$ primarily derives from $C 3$ trees and shrubs.

$A b b .1$ : Korrelation von substanz-spezifischen Alkan- $\delta^{13} C$-Werten (dargestellt für $n C_{27}$ und $n C_{33}$ ) mit Gesamt- $\delta^{13} C$-Werten (Gesamt organischer Kohlenstoff, TOC) für einen Sediment-Bohrkern aus Argentinien (ZECH et al. 2009b). Die größere Amplitude von $\delta^{13} \mathrm{C}$ für $n C_{33}$ verglichen mit $\delta^{13} \mathrm{C}$ von $n C_{27}$ kann damit erklärt werden, dass $n C_{33}$ überwiegend von C3- oder C4-Gräsern stammt, wohingegen $n C_{27}$ hauptsächlich von C3 Bäumen und Sträuchern stammt. 
al. 2009b) and changes in the nitrogen (N-)cycle (ZECH et al. 2007; Schatz et al. 2010).

A more sophisticated analytical approach is the combination of biomarker- and stable isotope analyzes. From a technical point of view, this is mostly accomplished by the coupling of a GC to an IRMS via an 'online' combustion unit (GC-C-IRMS). Thus, the isotopic composition of individual biomarkers eluting successively from the GC-column can be determined to provide more specific information than bulk isotope analyzes (Glaser 2005; Glaser \& ZECH 2005; AmELung et al. 2008). ZECH et al. (2009b), for example, have shown for a sediment core from NE-Argentina that the $\delta^{13} \mathrm{C}$ values of all individual plant leaf-wax derived n-alkanes
$\mathrm{nC}_{27}, \mathrm{nC}_{29}, \mathrm{nC}_{31}$ and $\mathrm{nC}_{33}$ correlate significantly with bulk $\delta^{13} \mathrm{C}$. However, the isotopic variations are most pronounced for $\mathrm{nC}_{31}$ and $\mathrm{nC}_{33}$ (Fig. 1), which corroborates the fact that the n-alkane biomarkers $\mathrm{nC}_{31}$ and $\mathrm{nC}_{33}$ derive primarily from grasses and are thus very sensitive for $\mathrm{C} 3-\mathrm{C} 4$ changes, whereas $\mathrm{nC}_{27}$ and $\mathrm{nC}_{29}$ derive primarily from trees and shrubs ( $\mathrm{C} 3$ vegetation).

As the natural abundances of deuterium and ${ }^{18} \mathrm{O}$ in rainfall mainly depend on climatic factors, namely temperature (Fig. 2) and the amount of precipitation (CRAIG 1961; DANSGAARD 1964; GAt 1996; Araguas-Araguas et al. 2000), $\delta D$ and $\delta^{18} \mathrm{O}$ records from LPS would be of great value, too. It is no surprise that various kinds of archives and chemical

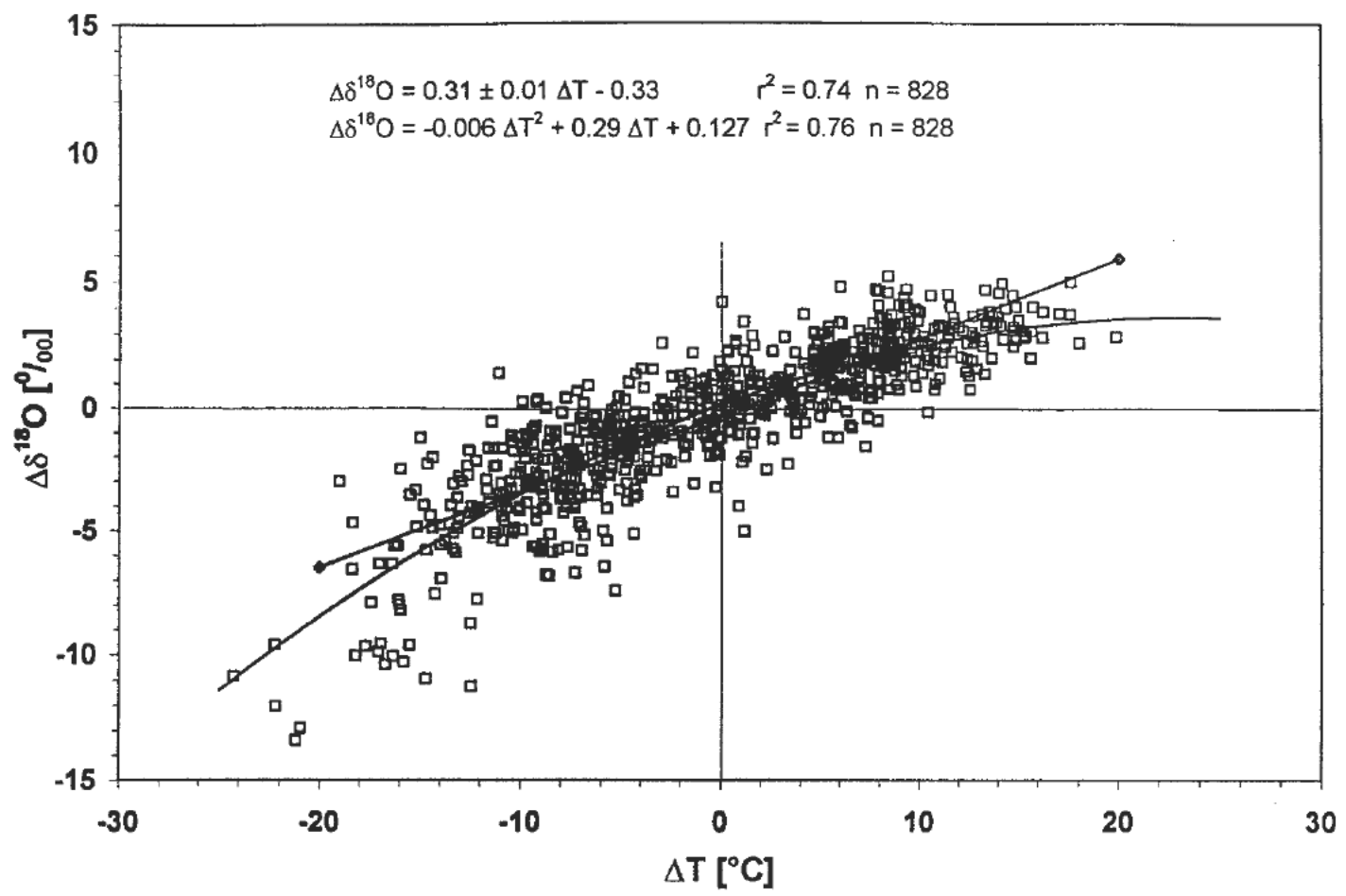

Fig. 2: Correlation between $\delta^{18} \mathrm{O}$ of monthly precipitation and surface air temperature for the IAEA/WMO network stations situated between $40{ }^{\circ} \mathrm{N}$ and $60^{\circ} \mathrm{N}$ (from ArAGUAS-ARAGUAS et al. 2000, Fig. 4a).

Abb. 2: Korrelation von $\delta^{18} \mathrm{O}$ im monatlichen Niederschlag mit Luftemperatur für IAEA/WMO Klimastationen $z$ wischen $40{ }^{\circ} \mathrm{N}$ und $60{ }^{\circ} \mathrm{N}$ (aus ARAGUASARAGUAS et al. 2000, Abb. 4a).

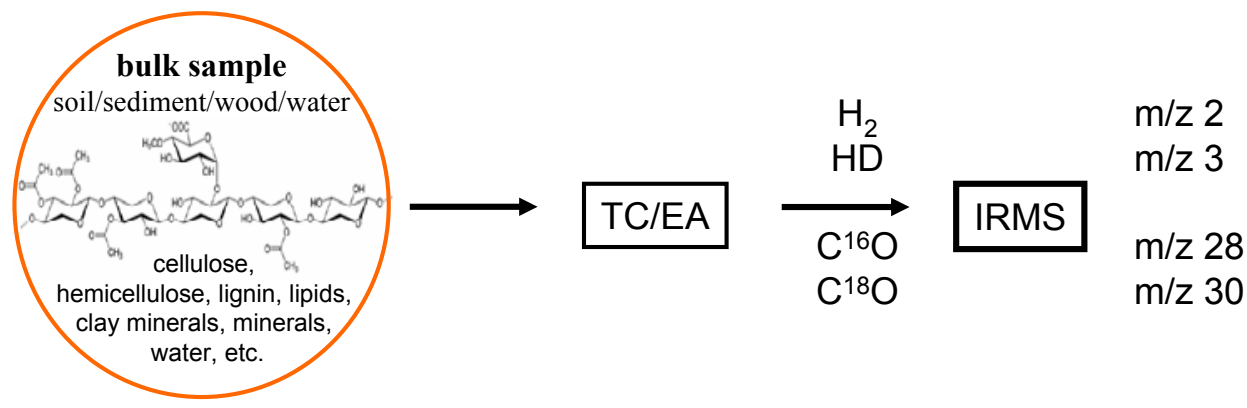

Fig. 3: Principle of bulk TC/EA-IRMS $\delta D$ and $\delta^{18} O$ analyzes. All hydrogen/oxygen atoms of a sample are converted at high temperature into hydrogen $\left(\mathrm{H}_{2}\right)$ / carbon monoxide (CO), for which $\delta D$ and $\delta^{18} \mathrm{O}$ are determined 'online' via a coupled IRMS by detecting the masses $m / z 2$ and 3 , and $m / z 28$ and 30 , respectively.

Abb. 3: Prinzip von Gesamt TC/EA-IRMS $\delta D$ und $\delta^{18} O$ Analysen. Alle Wasserstoff-/Sauerstoff-Atome einer Probe werden bei hoher Temperatur in Wasserstoff- $\left(\mathrm{H}_{2}\right)$ / Kohlenmonoxid- (CO) Gas umgewandelt. Mittels eines, online' gekoppelten IRMS werden für diese Gase die $\delta D$ bzw. $\delta^{18} \mathrm{O}$-Werte durch Detektion der Massen $\mathrm{m} / \mathrm{z} 2$ und $3 \mathrm{bzw} . \mathrm{m} / \mathrm{z} 28$ and 30 gemessen. 
compounds that record the deuterium and ${ }^{18} \mathrm{O}$ signatures of precipitation have been targeted extensively in paleoclimate studies, including ice cores, speleothems, lacustrine and pedogenetic carbonates, and plant cellulose (e.g. STERNBERG 1988; MAYER \& SCHWARK 1999; e.g. DANIS et al. 2006; WANG et al. 2006; GessLer et al. 2009). However, these proxies are hardly applied to LPSs so far.

From an analytical point of view, $\delta \mathrm{D}$ and $\delta^{18} \mathrm{O}$ analy-zes of bulk samples can be carried out via thermo conversion/elemental analysis (TC/EA-) IRMS 'online' coupling on pyrolytically produced hydrogen $\left(\mathrm{H}_{2}, \mathrm{HD}\right)$ and carbon monoxide $\left(\mathrm{C}^{16} \mathrm{O}, \mathrm{C}^{18} \mathrm{O}\right.$ ), respectively (WERnER et al. 1996; KornexL et al. 1999; Werner 2003) (Fig. 3). However, oxygen and hydrogen occur in many different organic and inorganic pools in soils and sediments (crystal water, aliphatic compounds, aromatic compounds, alcohols, plant-derived organic material, microbial-derived organic material, etc.). As these pools can have distinct isotopic signals, it is very difficult to disentangle a real paleoclimatic signal when changes in pool sizes cannot be excluded. Another metho-dological shortcoming is that many hydrogen and oxygen atoms are not strongly bound and that they are therefore prone to exchange reactions (Schimmelmann et al. 2006). Consider for example R$\mathrm{COOH}$ (carboxyl-) groups, where the isotopes will equilibrate (post-depositionally) with the ambient soil water. We will discuss ways to overcome these problems further below.

\section{Novel methodological approaches}

\subsection{Plant leaf-wax derived n-alkanes}

n-Alkanes with 25 to 33 carbon atoms $\left(\mathrm{nC}_{25}-\mathrm{nC}_{33}\right)$ and a strong odd-over-even predominance (OEP) are important constituents of cuticular plant leaf waxes (EgLINGTON \& HAMilton 1967; KolatTuKudy 1976). With the litter-fall they are deposited and stored in soils and sediments, for example in aeolian sediments, where they are assumed to be relatively resistant against biogeochemical degradation
(CRANWell 1981; LichtFouse 1998; LichtFouse et al. 1998). Since different vegetation types have distinct n-alkane patterns and hence a so-called "chemical fingerprint", n-alkanes have the potential to serve as biomarkers. For instance, they are used to differentiate between autochthonous (lacustrine) and allochthonous (terrestrial) organic matter in lake sediments (BourbonNiERE et al. 1997; Ficken et al. 2000; MüGLER et al. 2008; ZECH et al. 2009b), or to reconstruct vegetation changes, predominantly in terms of the relative proportions of grasses and trees (CRANWELL 1973; SCHWARK et al. 2002; ZECH 2006). The latter is based on the finding that the $\mathrm{n}$-alkanes $\mathrm{nC}_{27}$ and $\mathrm{nC}_{29}$ dominate in most modern trees and shrubs, whereas $\mathrm{nC}_{31}$ and $\mathrm{nC}_{33}$ dominate in grasses.

n-Alkanes can be easily extracted from dried and grin-ded plant $(\sim 0.5 \mathrm{~g}$ ) or sediment samples (up to $150 \mathrm{~g}$ ) with accelerated solvent extraction (ASE) or Soxhlet systems (e.g. WIESENBERG et al. 2004). In the method described for instance by ZECH \& GLASER (2008), an azeotropic methanol/toluene mixture (7/3) is used as solvent and deuterated n-tetracosane $\left(d_{50}-n-C_{24}\right)$ as internal standard. The extracts are concentrated and co-eluted esters are saponified with $0.5 \mathrm{M} \mathrm{KOH}$ in methanol. Purification of the $\mathrm{n}$-alkane fraction is performed on aluminium oxide/silica gel columns (both $5 \%$ deactivated) with hexane/toluene (85:15) as eluent. After concentration of the hydrocarbon fraction using rotary evaporation, deuterated n-eicosane $\left(\mathrm{d}_{42}-\mathrm{n}-\mathrm{C}_{20}\right)$ is added as recovery standard and the n-alkanes are quantified by injection into an HP 6890 GC equipped with a flame ionization detector (FID). Fig. 4 illustrates exemplarily a GC-FID n-alkane chromatogram for a loess sample from the 'Crvenka' LPS, Serbia.

Although the n-alkane biomarker method itself is known already for many decades, it is applied to LPS only relatively recently (LiU \& HuANG 2005; ZHANG et al. 2006; BAI et al. 2009). ZECH et al. (2008a) pointed out that the n-alkane patterns change over time and that a correction procedure is necessary to account for this degradation effect and to avoid deceptive interpretations when reconstructing vege-tation changes from sedimentary n-alkanes. Two correction proce-

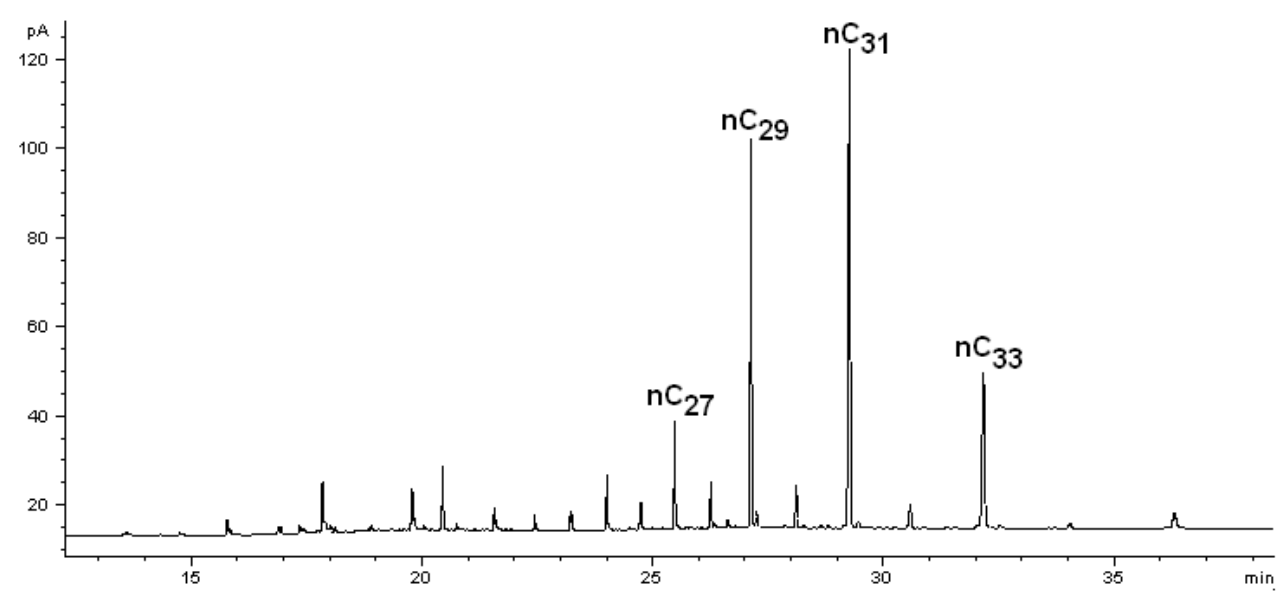

Fig. 4: GC-FID n-alkane chromatogram for a loess sample from Crvenka, Serbia. The highest abundance of $n C_{31}$ indicates a former vegetation cover dominated by grasses; the relatively higher abundance of $n C_{27}, n C_{29}, n C_{31}$ and $n C_{33}$ compared to $n C_{26}, n C_{28}, n C_{30}$ and $n C_{32}$ is called odd-over-even predominance (OEP) and indicates little degradation.

Abb. 4: GC-FID n-Alkan-Chromatogramm für eine Lössprobe aus dem Profil Crvenka, Serbia. Die Dominanz des Alkans $n C_{31}$ belegt, dass die frühere Vegetation überwiegend aus Gräsern bestand; das stärkere Auftreten von $n C_{27}, n C_{29}, n C_{31}$ und $n C_{33}$ verglichen mit $n C_{26}, n C_{28}, n C_{30}$ und $n C_{32}$ bezeichnet man als odd-over-even predominance (OEP) und ist charakteristisch für wenig stark degradiertest pflanzliches Ausgangsmaterial. 
dures have meanwhile been suggested, both of which employ the odd over even predominance (OEP) as degradation index (ZECH et al. 2009a; BugGLE et al. 2010).

\section{Case study: Vegetation reconstruction in the Carpathian Basin}

Based on pollen findings it is widely assumed that tree-less tundra expanded vast areas of Europe during glacial periods. For the Carpathian Basin, this traditional paradigm of treeless full glacial (stadial) paleoenvironments has first been called into question by fossil charcoal and malacological evidence from Hungarian LPSs (WILLIS et al. 2000; RUDNER \& SüMEgI 2001). The studies of SchATZ et al. (2011) and ZECH et al. (2009a) were initiated to contribute to the discussion about "trees or no trees?" (WILLIS \& ANDEL 2004) from an n-alkane biomarker perspective. In order to estimate the percentage contribution of n-alkanes (trees versus grasses) to the Crvenka LPS in Northern Serbia, ZECH et al. (2009a) proposed an end member modelling approach based on modern reference samples. This approach is illustrated exemplarily for the nalkane ratio $\left(\mathrm{nC}_{31}+\mathrm{nC}_{33}\right) /\left(\mathrm{nC}_{27}+\mathrm{nC}_{29}\right)$ in Fig. 5A. The results, taking degradation effects into account, allowed the authors to infer that grasses always dominated during the whole last glacial cycle, but that a small contribution of trees is likely during the glacial periods and the Holocene. Note that the accuracy of the n-alkane biomarker method is limited by the scattering of the modern datasets for grasslands and forests (Fig. 5A). This large interspecie variability can be attributed for instance to leaf and needle aging (PrüGEL et al. 1994) or to environmental stress (SHEPHERD \& GRIFFITHS 2006). Fig. 5B illustrates that this can result in 'negative' tree cover percentages. Yet the modelling results for several relevant nalkane ratios $\left[\left(\mathrm{nC}_{31}+\mathrm{nC}_{33}\right) /\left(\mathrm{nC}_{27}+\mathrm{nC}_{29}\right), \mathrm{nC}_{31} / \mathrm{nC}_{27}, \mathrm{nC}_{33} / \mathrm{nC}_{27}\right.$, and $\left.\left.\mathrm{nC}_{31} / \mathrm{nC}_{29}\right)\right]$ all reveal very similar and systematic shifts, which increases the confidence that degradation-corrected n-alkane patterns can be used to reconstruct past changes in vegetation. Accordingly, the n-alkane biomarker results of both ScHATz et al. (2011) and ZECH et al. (2009a) provide additional evidence challenging the paradigm of treeless full glacial paleoenvironments.

The reliability of $n$-alkanes as well as most other biomarkers as proxies in loess-paleosol sequences depends on the absence of strong post-sedimentary overprinting of the original organic matter signal. We highly acknowledge efforts aiming at quantifying such effects and point to studies published by Gocke et al. (2010) for rhizoliths in loess. The authors found that the n-alkane patterns of rhizolith organic matter are dominated by $\mathrm{nC}_{31}$ (Gocke et al. 2010, Fig. 6), Although this is not typical for above-ground lipids from most trees and shrubs but for grasses, the authors favor post-sedimentary incorporation of root-derived orga-nic matter in loess. Further studies should therefore firstly address n-alkane concentrations in roots as the latter are assumed to be very low compared to above-ground litter; secondly, datasets for modern reference n-alkane patterns from roots, lacking so far, should be established. And thirdly, we
A)

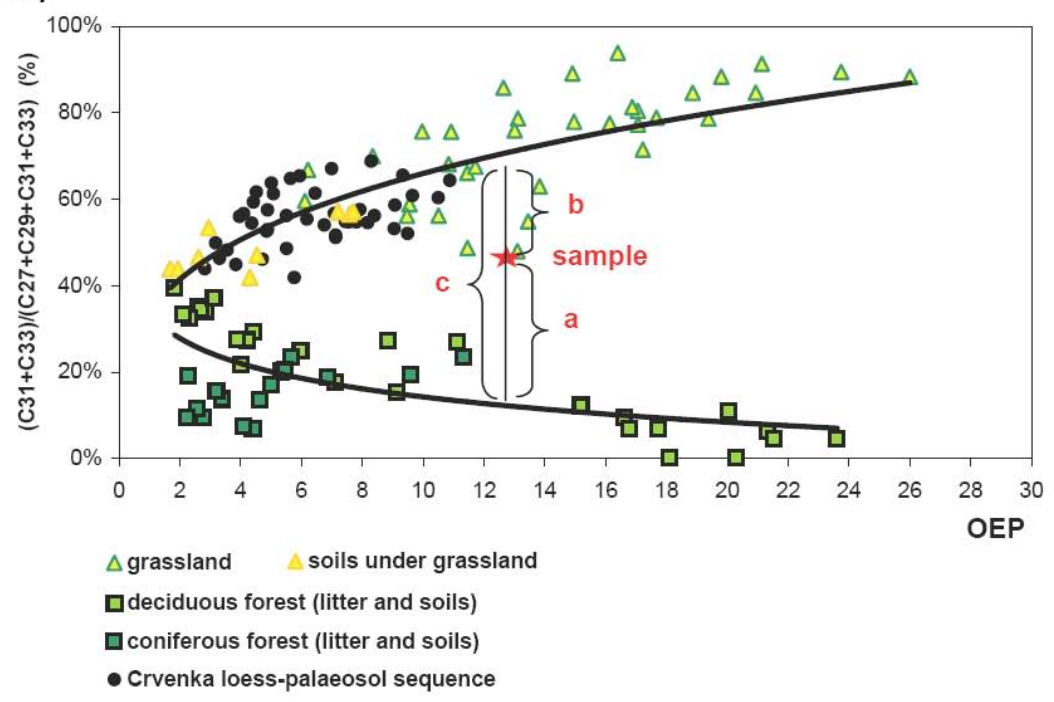

B)

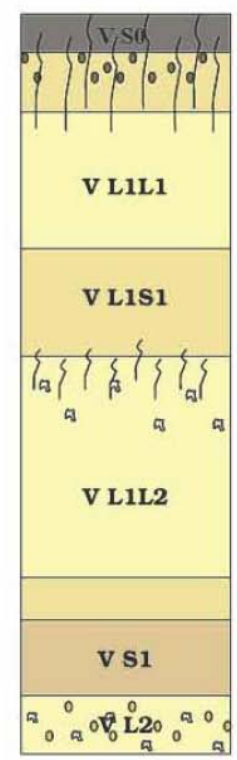

alkanes derived from trees

alkanes derived from grasses and herbs

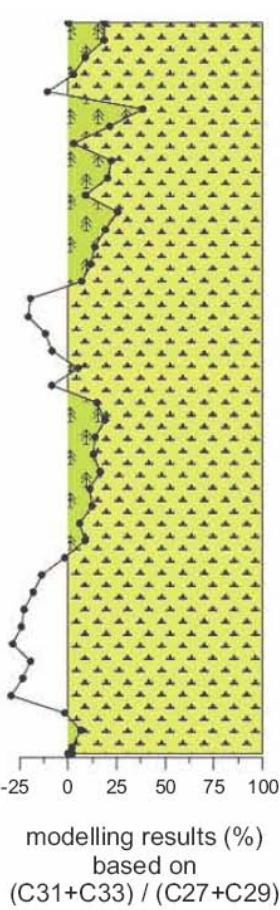

Fig. 5: A) End member modelling approach for the $n$-alkane ratio $\left(n C_{31}+n C_{33}\right) /\left(n C_{27}+n C_{29}\right)$. Based on modern plant and soil $n$-alkane ratios, degradation lines are calculated using the OEPs as degradation proxy. The percentage of trees and grasses contributing to a loess-paleosol sample is estimated by the quotients b/c and a/c, respectively. B) Pedostratigraphy of the Crvenka LPS in Northern Serbia and modelling results for the contribution of tress and grasses (adopted from ZECH et al. 2009a).

Abb. 5: A) End Member Modell für das n-Alkanverhältnis $\left(n C_{31}+n C_{33}\right) /\left(n C_{27}+n C_{29}\right)$. Basierend auf $n$-Alkanverhältnissen von rezenten Pflanzen und Böden werden Degradationslinien ermittelt. Die OEP-Werte dienen dabei als Proxy für den Degradationsgrad. Die Anteile von Baum- bzw. Gras- $n$-Alkanen zu einer LPS-Probe lassen sich anhand der Quotienten b/c bzw. a/c abschätzen. B) Pedostratigraphie der LPS Crvenka in Nordserbien und ModellierungsErgebnisse für die Anteile von Bäumen im Vergleich zu Gräsern (aus ZECH et al. 2009a). 
highly encourage further investigations especially applying compound-specific ${ }^{14} \mathrm{C}$-dating of different biomarkers in LPS for which independent and high resolution luminescence dating of the sedimentary history is available.

\subsection{Amino acid racemization}

Amino acids, mainly bound in proteins, constitute an important N-pool in soils (AMELUNG 2003). They are no bio-markers sensu strictu, because they do not originate from specific organisms. However, they may provide valuable insights in the aging of soil organic matter (SOM) and past temperatures. Amino acids contain a chiral $\mathrm{C}$-atom, and they can therefore occur either in the left-handed form (L-enantiomer) or in the right-handed form (D-enantiomer). Living organisms primarily produce L-amino acids, but the D-enantiomers are then formed during racemization - an abiotic process that is mainly time-, temperature- and $\mathrm{pH}$-dependent (BADA 1985) (Fig. 6). It has therefore been suggested that D/L-ratios of amino acids can be used for dating. MAHANEY \& RutTER (1989), for instance, found the D/L-ratio of aspartic acid to be a suitable geochronometer in buried soils. For the last 15 years, amino acid geochronology in loess research was mainly based on measuring the ratio alloisoleucine/isoleucine in fossil gastropod shells and was successfully used to distinguish between loess from different glacial cycles (ZöLLER et al. 1994; Oches \& McCoy 2001; Novothny et al. 2009). Principally, of course, amino acid racemization could also be used to reconstruct paleotemperatures, but independent age control needs to be available, and such applications are very rare so far (KAUFMAN 2003).

Most geochronological studies have focussed on amino acids in fossil gastropod shells, based on the notion that these likely provide the best 'closed systems' available, i.e. that postdepositional amino-acid losses or contamination are minimal (Penkman et al. 2008). Amelung \& ZHANG (2001), however, also proposed a method for determining amino acid enantiomers in bulk soil samples. Sample preparation comprises pre-extraction of free and water-soluble amino acids, hydrolysis of protein-bound amino acids, purification over columns (Dowex W X8), and derivatization. Quantification is carried out using GC-MS. As racemization is known to be catalysed by low $\mathrm{pH}$ and high temperatures, conditions that are also applied during hydrolysis, AmElung \& BRODOwsKI (2002) quantified the hydrolysis-induced racemization using deuterium labelling. They show that less than $10 \%$ of D-Asp and D-Lys were formed during the analytical procedure in environmental samples older than 3000 years. Hence, AMELUNG (2003) suggested that aspartic acid (asp) and lysine (lys) are the most suitable amino acids for dating purposes in soils.

\section{Case study: Temperature reconstruction in Siberia}

ZECH et al. (2008b) applied the method of AMELUNG \& ZHANG (2001) to 10 selected samples from a Siberian permafrost LPS ('Tumara'), which probably comprises the last two glacial cycles. For details concerning the (chrono-) stratigraphy, the geochemical, the isotopic and the biomarker characterization of this sequence the reader is referred to ZECH et al. (2007; 2008b; 2010a). In brief, dark organic-rich paleosols alternate with brown and more intensively mineralised and weathered paleosols (Fig. 7). Based on numeric dating results and a multi-proxy approach, the dark units B, C2 and D are correlated with glacial periods, whereas the brown units $\mathrm{A}, \mathrm{C} 1$, $\mathrm{C} 2$ and $\mathrm{E}$ are correlated with interglacial/-stadial periods. The $\mathrm{D} / \mathrm{L}$ ratios obtained for aspartic acid (asp) and lysine (lys) are plotted versus depth in Fig. 7 and can be roughly described by exponential fits. In addition, the brown units are generally characterized by higher ratios than the dark grey units. Nevertheless, D/L ratios overall increase with depth and reveal that the apparent racemization rates are smaller for lysine than for aspartic acid (the latter having higher D/L ratios). This is in agreement with findings from Amelung (2003), who furthermore emphasised that lysine racemization rates are more or less constant in different soil types. Given that the soil $\mathrm{pH}$ reveals only minor variations ranging from 7 to 8 throughout the whole profile, temperature and time can be assumed to be the main factors controlling the
A)

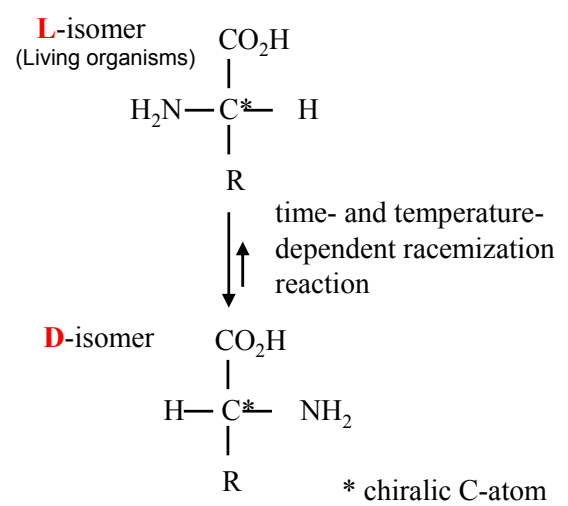

B)

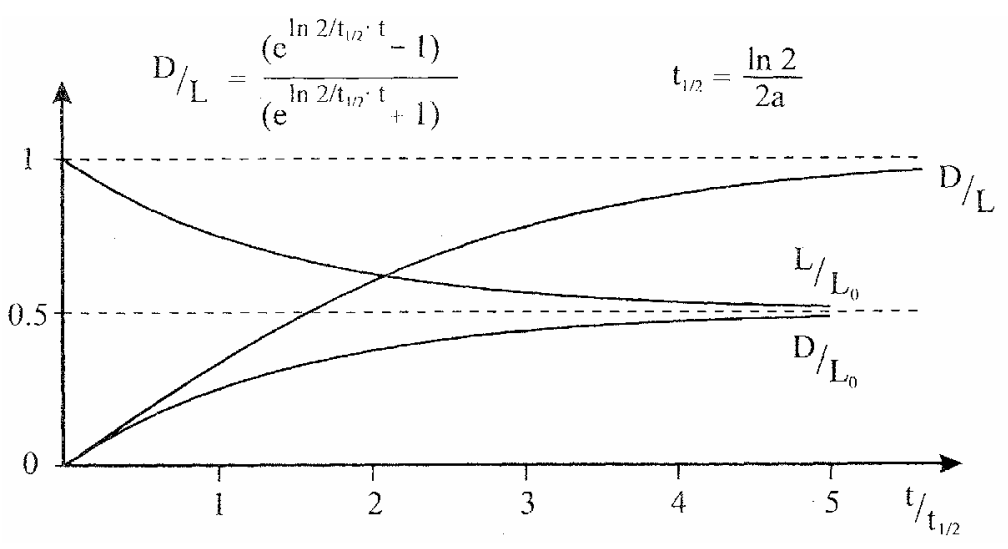

Fig. 6: Principle of amino acid geochronology: A) Time- and temperature-dependent racemization reaction. B) Exponential functions describing the time-dependency of racemization; $t 1 / 2=$ half-life time, $L 0=$ initial amount of L-enantiomers, $D / L=$ ratio of $D$ - to L-enantiomers (from WAGNER 1998, p. 342, Fig. 142 ).

Abb. 6: Prinzip der Aminosäure-Geochronology: A) Die zeit- und temperaturabhängige Gleichgewichtsreaktion der Razemisierung. B) Exponentielle Funktionen die die Zeitabhängigkeit der Razemisierung beschreiben; $t 1 / 2=$ Halbwertszeit, L0 = Anfangsgehalt des L-Enantiomers, D/L = Verhältnis von D- zu L-Enantiomeren (aus WAGNER 1998, Seite 342, Abb. 142). 
amino acid racemization. Consequently, ZECH et al. (2008b) suggest that the higher $\mathrm{D} / \mathrm{L}$ ratios that characterize the brown Units $\mathrm{A}, \mathrm{C} 1$ and $\mathrm{C} 3$ are primarily the result of higher temperatures during formation of the respective paleosols.

Based on these results, we see high potential for the amino acid racemization method to provide a paleotemperature proxy in LPS. A high sampling resolution might also help depicting sedimentary hiatuses, which should yield abrupt increases of the D/L ratios with depth. Unfortunately, the described method is relatively laborious and will require some further optimisation, particularly for the application to organic-poor loess samples. An important step would probably be already made when using a HPLC instead of a GC system, because that will supersede the derivatization step.

\subsection{GDGTs}

Over the last few years, several new proxies have been proposed based on GDGTs (Fig. 8), membrane lipids of Archaea and Bacteria. The exact chemical composition of the GDGTs is thought to reflect adjustments of membrane permeability and fluidity to environmental conditions (e.g. $\mathrm{pH}$ and temperature). Thus the analyzes of GDGTs may offer interesting, new approaches to quantitatively reconstruct past climate and environmental variability from various geological archives. The $\mathrm{TEX}_{86}$, for example, is a new paleotemperature proxy based on the cyclicity of isoprenoid GDGTs, which are mainly derived from Archaea living in oceans and lakes (Schouten et al. 2002; KIM et al. 2008; Powers et al. 2010). Although it has meanwhile been found that isoprenoid

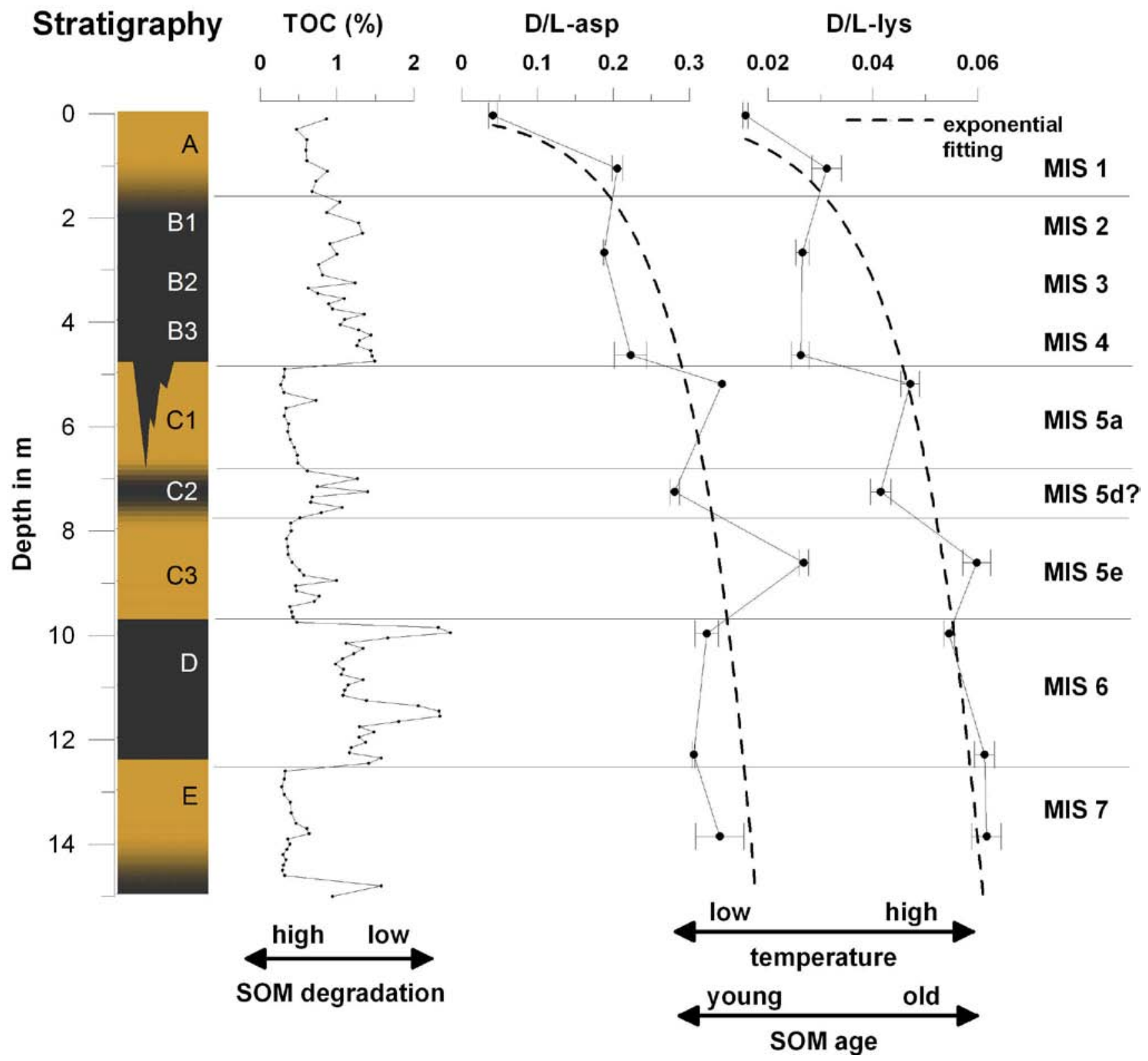

Fig. 7: Stratigraphy and tentative chronostratigraphy of the Tumara LPS, NE-Siberia. D/L-ratios for Asp and Lys increase with depth, reflecting the time dependency of the racemization. Higher ratios in the brown units compared to lower ratios in the dark units are suggested to reflect the temperature dependency of amino acid racemization (from ZECH et al. 2008b).

Abb. 7: Stratigraphie und Chronostratigraphie der LPS Tumara, NO-Sibirien. D/L-Verhältnisse für Asp and Lys werden mit zunehmender Tiefe weiter. Dies spiegelt die Zeitabhängigkeit der Razemisierung wider. Weitere Verhältnisse in den braunen Paläoböden verglichen mit den dunklen Paläoböden lassen sich mit der Temperaturabhängigkeit der Razemisierung erklären (aus ZECH et al. 2008b). 
GDGTs also occur in soils, another proxy, the BIT (branched versus isoprenoid GDGTs), has been suggested to allow the quantification of terrestrial versus autochthonous organic matter in lacustrine and marine sediments (SCHOUTEN et al. 2002). This index is further based on the original assumption that branched GDGTs are only derived from soil-thriving bacteria. Meanwhile, however, it has been found that branched GDGTs are also produced within the water column of oceans and lakes (BlagA et al. 2009; Peterse et al. 2009a; Bechtel et al. 2010; Tierney et al. 2010), which warrants caution when interpreting the BIT and $\mathrm{TEX}_{86}$ indices.

The branched GDGTs, which are presumably derived from yet unknown anaerobic, heterotrophic soil bacteria (WEIJERS et al. 2010), may be promising biomarkers for loess-paleosols research. An empirical study based on 134 soil samples from 90 globally distributed locations has shown that branched GDGTs vary in their degree of cyc-lisation and methylation (expressed as CBT and MBT, i.e. cyclisation and methylation index of branched tetraethers) depending on soil $\mathrm{pH}$ $\left(\mathrm{R}^{2}=0.70\right)$ and mean annual air temperature (MAAT, $\mathrm{R}^{2}=$ 0.82) (WeijERs et al. 2007). Local calibration studies along altitudinal transects at Mt. Kilimanjaro, Tanzania, and Mt. Gongga, China, have meanwhile corroborated the suggested $\mathrm{pH}$ and temperature dependency of the CBT/MBT indices (Schouten et al. 2002; Peterse et al. 2009b). The analysis of branched GDGTs in lake and ocean sediments might there- fore provide a valuable, new proxy for catchment-wide $\mathrm{pH}$ and MAAT reconstructions, provided that they are derived from eroded soils only. As mentioned above, however, there is evidence that branched GDGTs are also produced autochthonously in lakes and oceans, which prevents robust interpretation of the CBT and MBT indices in respective studies thus far. Surpri-singly, to our knowledge, no studies have been published yet applying the CBT/MBT indices for paleoenvironmental reconstructions in loess-paleosols.

The analysis of GDGTs comprises (i) lipid extraction from typically freeze-dried soil or sediment samples (5-50 $\mathrm{g}$ depending on abundance), (ii) separation into the apolar and polar (containing the GDGTs) fraction over a $\mathrm{Al}_{2} \mathrm{O}_{3}$ column using e.g. hexane:dichloromethane (DCM) (9:1) and DCM:Methanol (1:1), and (iii) filtering, prior to quantification of the various GDGTs by HPLC/atmospheric pressure chemical ionization-mass spectrometry (APCI-MS). So-called selective ion monitoring allows detecting specific molecular masses, i.e. specific GDGT molecules (Fig. 8).

\section{Case studies: Application of GDGT indices to the Tumara} LPS, Siberia, and Crvenka LPS, Serbia

The first case study presents GDGT results from the $\mathrm{Tu}^{-}$ mara LPS (Fig. 9). The BIT indices are generally high $(>0.84)$, which is in agreement with the notion that branched GDGTs are mainly derived from soil-thriving

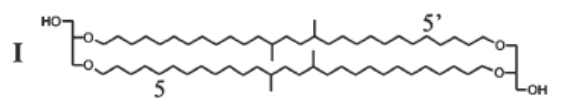

$m / z$
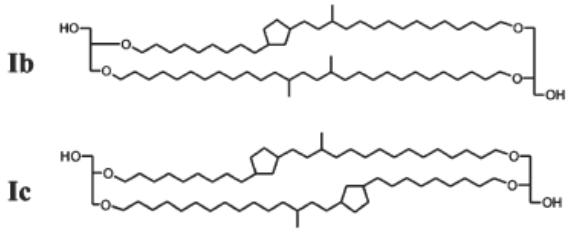

1018
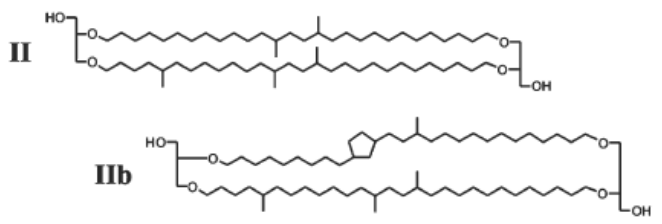

1034
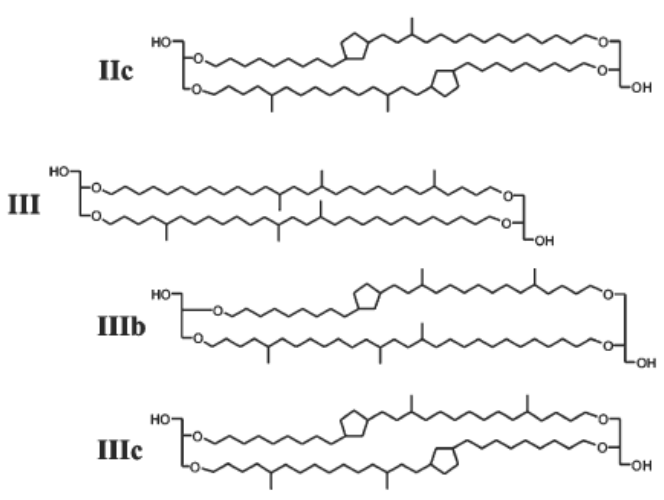

1046
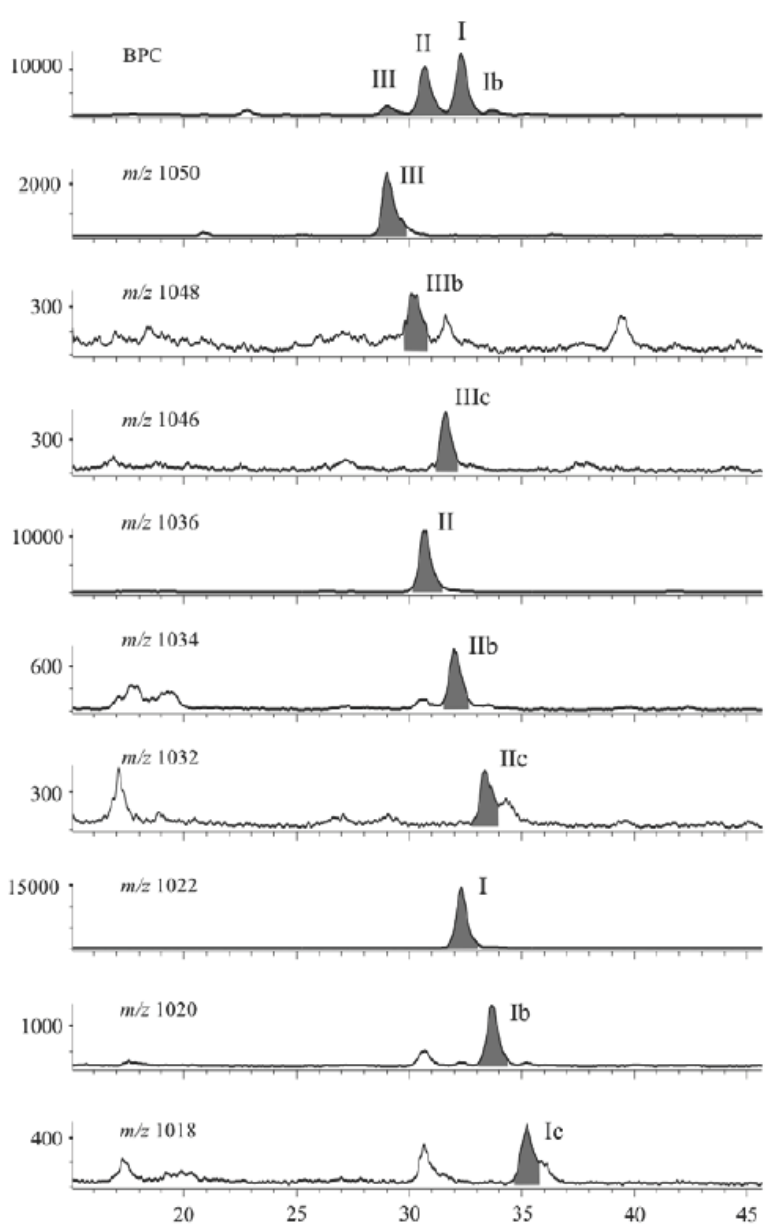

Fig. 8: Chemical structures of the branched GDGTs (left), and total and selective ion mass [M+H]+ chromatograms for a soil sample (modified after WEIJERS et al. 2007).

Abb. 8: Chemische Strukturen für verzweigte GDGTs (links), und Chromatogramme für die Gesamtmasse bzw. einzelner Massen [M+H]+ für eine Bodenprobe (abgeändert nach WEIJERS et al. 2007). 


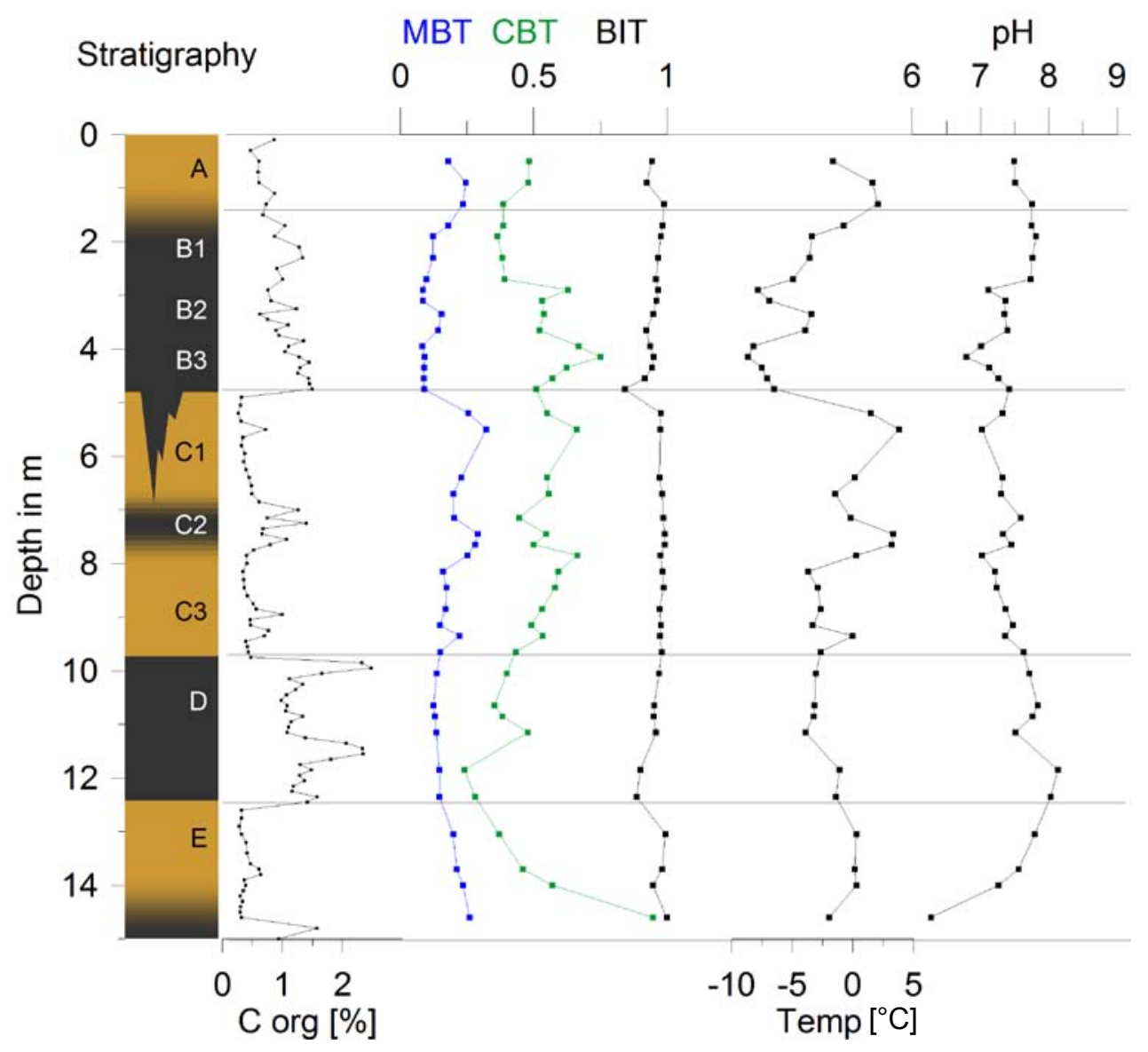

Fig. 9: Pedostratigraphy of the Tumara LPS, NE-Siberia, GDGT indices MBT, CBT and BIT, and reconstructed temperatures and soil pH. While the reconstructed relative interglacial-glacial temperature variability in the upper $7 \mathrm{~m}$ of the profile is in agreement with the expected temperature variability derived from the chronostratigraphy, reconstructed temperatures for the presumably penultimate glacial Unit D seem to be too high.

Abb. 9: Pedostratigraphie der LPS Tumara, NO-Sibirien, GDGT Kennzahlen MBT, CBT und BIT, sowie die rekonstruierten Temperaturen und Boden pHWerte. Während die rekonstruierten relativen interglazial-glazial Temperaturschwankungen in den oberen 7 Metern des Profils der Chronostratigraphie übereinstimmen, scheinen die rekonstruierten Termperaturen im vorherigen, älteren Glazial zu hoch zu sein.

bacteria. The MBT indices range from 0.08 to 0.32 , and the CBT ranges from 0.24 to 0.95 . This translates into reconstructed MAAT between -8.7 and $3.8^{\circ} \mathrm{C}$, and soil $\mathrm{pH}$ between 6.3 and 8.1.

Replicate measurements of a soil standard ("Yongsong's garden") throughout the course of the measurements indicate laboratory precision of $0.2^{\circ} \mathrm{C}$ for MAAT, and 0.01 for $\mathrm{pH}$. However, much higher uncertainties regarding the accuracy of the reconstructed parameters may arise for several reasons:

(i) The reconstructed temperatures for the Tumara LPS are partly well below $0^{\circ} \mathrm{C}$ and thus beyond the lowest values in the global calibration data set. Although a recent study in Svalbard indicates that mean annual air temperatures below $0^{\circ} \mathrm{C}$ may be successfully reconstructed using branched GDGTs (PETERSE et al. 2009a), comparison of our uppermost sample $\left(-1.7^{\circ} \mathrm{C}\right)$ with estimated MAAT of $\sim-15^{\circ} \mathrm{C}$ suggests a significant positive bias. At this stage, we can only speculate that the observed discrepancy might be due to seasonal (summer) growth of the soil bacteria, differences between MAAT and soil temperatures, or other unknown methodological shortcomings.

(ii) Analytical challenges regarding the new proxies have become evident, because one of the target compounds (m/z 1050, III in Fig. 10a), which is generally characterized by a minor "contamination" shoulder on the right side, turned out to be dominated by that "contamination" (compound III, probably an isomer of III (WeIJERs et al. 2010)). When coupling two HPLC columns to achieve better peak separation, it is possible to quantify the two compounds individually (Fig. 10b, Y. Huang, pers. comm.). However, no calibration studies are available yet that take the separated compounds into account. Moreover, other target peaks also turned out to consist of multiple, yet unidentified compounds. Clearly, further research is necessary to improve compound separation and identification.

(iii) There are two other effects that might constrain the applicability of GDGT-based reconstructions in loesspaleosols, which we refer to here as "changing community effect" and "growth depth effect": The first one addresses the possibility that changes in the GDGT-producing bacterial communities could result in changes in the structural composition of the membrane lipids without necessarily reflecting changes in environmental conditions. In that sense, as long as the GDGT-producing organisms are not identified, cultured and tested individually, we have to rely on empirical calibration studies as they exist today even if they do not fully capture all possible factor affecting GDGD distributions.

The "growth depth effect" has to do with the fact that we 
still know very little about the soil bacteria's ecology, including for example the soil depth at which the bacteria thrive and produce GDGTs. A non-negligible subsurface production of GDGTs could thus result in an overprint of 'older' paleo-environmental signals at depth. The growth depth effect might limit the temporal resolution of reconstructions, mute the variability of the real signal, and render 'absolute' reconstructions very challenging from loesspaleosols LPS.

With these methodological limitations in mind, the interpretation of paleo-data should be very cautious. Our first case study from Siberia shows that Unit A and C, which were most likely deposited during the Holocene and the Eemian, respectively, are characterized by higher reconstructed temperatures than the glacial Unit B (Fig. 9). Although the absolute MAAT are likely overestimated systematically, the glacial-interglacial temperature difference of $\sim 10^{\circ} \mathrm{C}$ is reasonable. One could also speculate that the last glacial pattern is real, with coldest conditions during Marine Isotope Stage (MIS) 2 and 4 and slightly warmer conditions during MIS3. Surprising features, however, are (i) relatively warm conditions during MIS2 compared to MIS4, (ii) Unit C not displaying a commonly expected temperature peak maximum for MIS5e (Unit C3, Fig. 9), and (iii) 'too warm' reconstructed temperatures for the penultimate glacial Unit D. Provided that the presented chronostratigraphy of the Tumara LPS is correct, our results suggest that the growth depth effect might have overprinted and muted the paleo-signals, i.e. warm conditions during the Holocene are now overprinting the cold MIS2 signal, and the very warm conditions during the Eemian have allowed GDGT-producing bacteria at depth to strongly affect the record below $5 \mathrm{~m}$ depth.

In our second case study for GDGTs, unpublished data from the Crvenka LPS (Fig. 11), pose similar challenges to a robust interpretation of GDGT indices. Here, the topsoil samples show reconstructed MAAT of $\sim 15^{\circ} \mathrm{C}$, which is in reasonable agreement with estimated MAAT of $11^{\circ} \mathrm{C}$, although with a slight bias to too high temperatures. Subsurface samples reach $20^{\circ} \mathrm{C}$ reconstructed temperatures, which might indeed reflect warmer conditions during the mid-
Holocene optimum. However, reconstructed temperatures remain very high in the underlying MIS2 loess (V L1L1). As above, we speculate that this might reflect that GDGTs were produced during the Holocene at depth and thus overprinted the cold, glacial signal. While reconstructed temperatures drop to values as low as $\sim 4^{\circ} \mathrm{C}$ deeper in the profile, which would be reasonable in terms of expected glacial-interglacial temperature variability, reconstructed lowest temperatures also characterize the interglacial Eemian paleosol V S1, although the latter should be characterized by highest temperatures. Is this again due to the growth depth effect? Or does this indicate other methodological shortcomings that are not yet fully understood? In summary, we advise caution when interpreting GDGTderived proxies from LPS. GDGT analyzes are a promising new tool for paleoclimate reconstruction, but there are many yet unresolved questions that need to be addressed before robust conclusions can be inferred from respective proxies.

\subsection{Compound-specific $\delta \mathrm{D}$-analyzes of $n$-alkanes}

As discussed earlier, both $\delta \mathrm{D}$ and $\delta^{18} \mathrm{O}$ have a high potential for paleoclimatic reconstructions. Albeit with certain biosynthetic fractionation factors, plant photosynthetic products incorporate the isotopic climate signal of precipitation, because their $\delta \mathrm{D}$ values are related to the source water $\delta \mathrm{D}$ values (Sternberg 1988; Sessions et al. 1999; SAuer et al. 2001; SACHSE et al. 2004). During soil organic matter formation, this climate signal is also inherited by soils. However, changing soil organic matter pool sizes (e.g. lipids, lignin, cellulose) and isotopic exchange reactions in soils and sediments have prevented the simple use of bulk analyzes (BALABANE 1983).

One approach to overcome at least the latter problem is to equilibrate bulk samples in water with known isotopic composition, and then to correct for the exchange reactions after bulk measurements via TC/EA-IRMS (RUPPENTHAL et al. 2010). Yet technical improvements now also allow a more elegant and more specific approach, namely determining the isotopic composition of individual biomarkers by coupling
A)

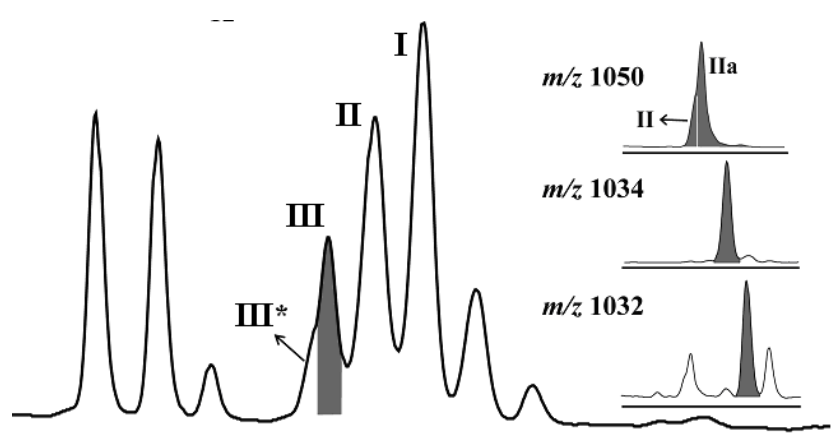

B)

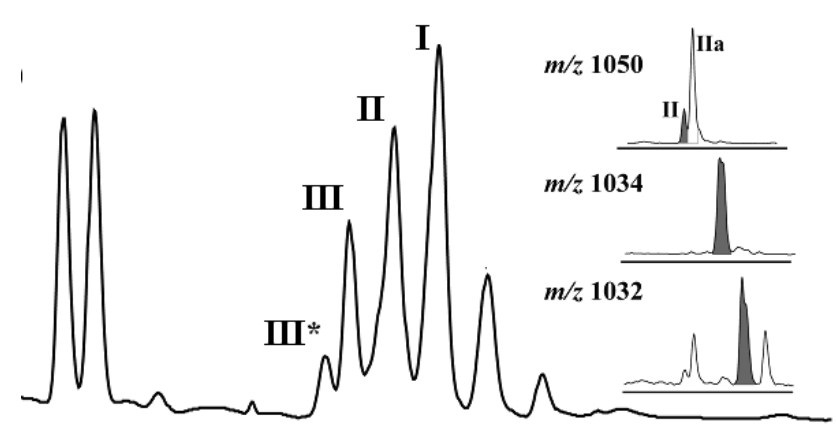

Fig. 10: Total ion chromatogram of one of the Siberian samples, illustrating the existence of two isomers III and III* for $m / z$ 1050. A) Standard chromatogram and B) chromatogram with improved peak separation.

Abb. 10: Beispiel für ein HPLC Chromatogramm der siberischen Proben. Es zeigt das Vorhandensein von zwei Isomeren mit der Massenzahl m/z 1050 (III

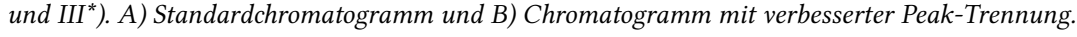




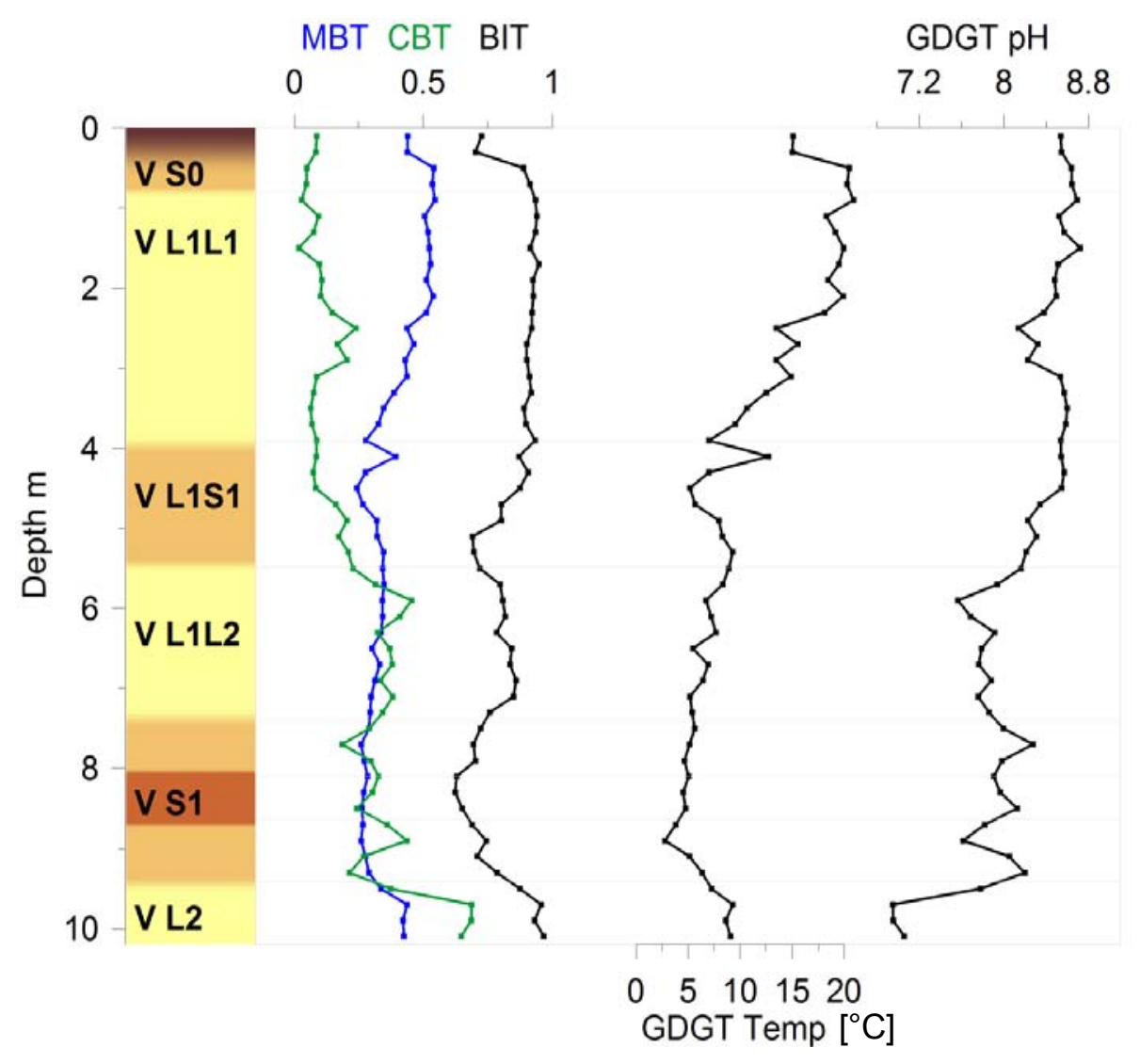

Fig. 11: Pedostratigraphy of the Crvenka LPS in Northern Serbia, GDGT indices MBT, CBT and BIT, and reconstructed temperatures and soil pH. Similar to the Tumara LPS, reconstructed GDGT temperatures are not always in agreement with what can be expected from the chronostratigraphy, e.g. lowest reconstructed temperatures coincide with the presumably last interglacial Eemian soil V S1. Possibly, the "growth depth effect" prevents a simple interpretation of GDGT proxies in LPSs.

Abb. 11: Pedostratigraphie der LPS Crvenka in Nordserbien, GDGT Kennzahlen MBT, CBT und BIT, und rekonstruierte Temperaturen und Boden pHWerte. Ähnlich wie bei der LPS Tumara, stimmen die rekonstruierten GDGT-Temperaturen nicht immer mit der Chronostratigraphie überein. Insbesondere überraschen die für den vermutlich letzt-interglazialen Eemboden V S1 rekonstruierten niedrigen Temperaturen. Eine einfache Interpretation der neuen Proxies in LPS ist möglicherweise durch das Wachstum von GDGT-produzierenden Archaebakterien in tieferen Bodenschichten erschwert.

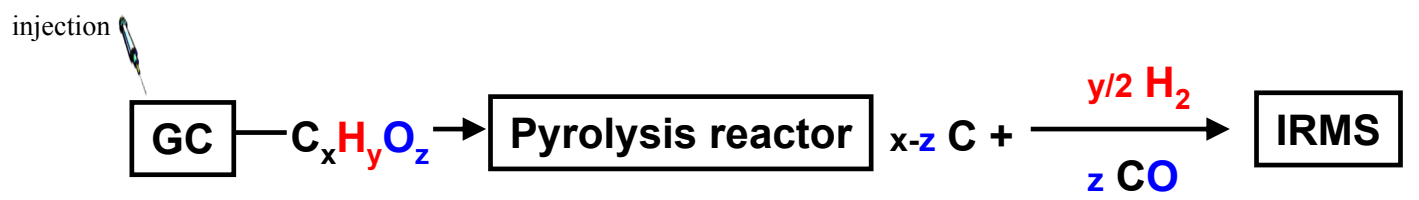

Fig. 12: Principle of compound-specific $\delta D$ - and $\delta^{18} O$-analysis of biomarkers using GC-Py-IRMS. Biomarkers eluting successively from the GC-column are converted "online" in a pyrolysis reactor to hydrogen $\left(\mathrm{H}_{2}\right)$ and carbon monoxide $(\mathrm{CO})$ and the isotopic composition of these gases are determined directly in a coupled IRMS.

Abb. 12: Prinzip der substanz-spezifischen $\delta D$ - und $\delta^{18} O$-Analytik von Biomarkern mittels GC-Py-IRMS. Die nacheinander von der GC-Säule eluierenden Biomarker werden im 'online' Verfahren in einem Pyrolysreaktor in Wasserstoff- $\left(\mathrm{H}_{2}\right)$ und Kohlenmonoxid-Gas (CO) umgewandelt. Die Isotopenzusammensetzung dieser Gase wird in einem direkt gekoppelten IRMS gemessen.

of GC and IRMS via an 'online' pyrolysis reactor (Py) (BurGOYNE \& HAYEs 1998; HiLKeRT et al. 1999) (Fig. 12)

With this new tool at hand, compound-specific $\delta \mathrm{D}$ became a popular paleoclimate proxy (LiU et al. 1999; HuANG et al. 2004; SAChSE et al. 2004; XIE et al. 2004; PAgAni et al. 2006; MÜGLER et al. 2008). Plant-derived $n$-alkanes are probably the most useful biomarkers to target, because they are well-preserved in sediments and soils (LichTFOUSE et al. 1998), and because their alkyl hydrogen atoms are less prone to exchange reactions compared to other biomarkers (Sessions et al. 2004; Pedentchouk et al. 2006; Dawson et al. 2007).

Of course, ultimately, one has to take into account that evaporative enrichment of soil and plant water, as well as biosynthetic fractionation are also important factors controlling the isotopic signature of the targeted biomarker (SCHMidt et al. 2001; Liv et al. 2006; SMITH \& FrEEMAN 2006; Barbour 2007; Hou et al. 2007; Feakins \& Sessions 2010). 
Two case studies: Paleoclimate reconstructions from $\mathrm{Tu}-$ mara and Crvenka

To our knowledge, the first and only application of compound-specific $\delta D$ analyzes of n-alkanes to a LPS was carried out by Liu \& HuANG (2005) on the Chinese Loess Plateau. We will here present two case studies based on own data to illustrate the methodological potentials and limitations. The first case study aimed at more quantitative temperature reconstruction for the Tumara LPS in Northeast Siberia (ZECH et al. 2010b). The $\delta \mathrm{D}$ records of all three n-alkanes that had sufficient concentration for the $\delta \mathrm{D}$ measurements $\left(\mathrm{nC}_{27},{ }_{29}\right.$ and $\left.{ }_{31}\right)$ show very similar patterns along the $\sim 240 \mathrm{ka}$ profile (Fig. 13). The authors therefore concluded that vegetation changes, which have been reconstructed for Tumara employing $n$-alkane patterns and pollen analyzes (ZECH et al. 2010a) did not play a dominant role for the isotopic signal. The mean $\delta \mathrm{D}$ record can thus be interpreted to reflect past changes in the isotopic composition of soil water, which in turn dominantly reflects temperature at high latitudes. More negative values $(-280 \%$ ) characterize the organic-rich Units B, C2 and D, which confirms our earlier interpretation that those units were deposited during cold, glacial conditions. More positive values (>-250\%) characterize the Units A, C1,

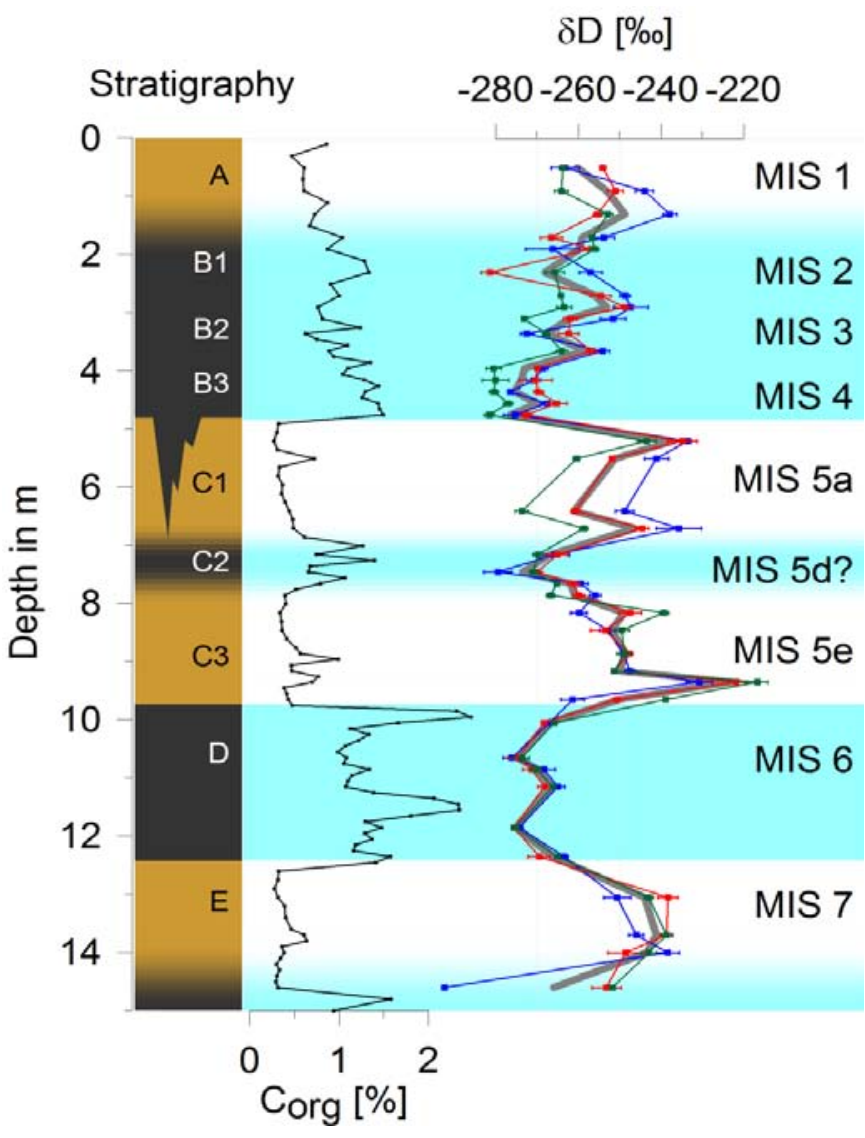

Fig. 13. Stratigraphy, organic carbon content $\left(C_{\text {org }}\right)$ and $\delta D$ measured on the $n$-alkanes $n C_{27}, n C_{29}$ and $n C_{31}$ (in blue, red and green; the mean value is displayed in grey) from the Tumara LPS. More negative $\delta D$-values are interpreted to reflect colder paleotemperatures. Correlation with marine isotope stages (MIS) is shown to the right (ZECH et al. 2010b).

$A b b$. 13. Stratigraphie, organischer Kohlenstoffgehalt $\left(C_{\text {org }}\right)$ und ermittelte $\delta D$-Werte für die $n$-Alkane $n C_{27}, n C_{29}$ und $n C_{31}$ (in blau, rot und grün; Mittelwerte in grau) der LPS Tumara. Stärker negative $\delta D$-Werte lassen sich mit kälteren Paläotemperaturen erklären. Die Korrelation mit den Marinen Isotopen Stadien (MIS) ist rechts dargestellt (aus ZECH et al. 2010b).
C3 and E, which is in agreement with deposition during warm, interglacial periods.

ZECH et al. (2010b) note that a correction could be applied for the fact that the glacial oceans and thus precipitation became more positive ( $~ 8 \%$, the global ice volume effect). This would increase the glacial-interglacial differences in the investigated record, but would require a more robust age control than the one being at hand. Another cautionary note is that changing evaporation might also have affected the presented record. ZECH et al. (2010b) suggested that evaporation effects are probably only of second-order importance at this site because of the low temperatures. Assuming that evaporation had a measurable effect, it should have led to isotopic enrichment during the more arid glacial periods. This might in fact explain the slightly smaller glacial-interglacial range in $\delta \mathrm{D}(\sim 30 \%)$ compared to respective ranges in ice core records (up to $50 \%$ ).

Our second case study presents unpublished $\delta D$ data for Crvenka. The n-alkanes $\mathrm{C}_{29}$ and ${ }_{31}$ were most abundant in the samples and therefore targeted for the $\delta \mathrm{D}$ measurements. Overall, the two records mostly track each other reasonably well (Fig. 14), although the measurement precision of 3.1 and $2.9 \%$ o for the external standards $\mathrm{nC}_{27}$ and $\mathrm{C}_{29}$, respectively (run during the course of the whole measurement period), as well as mean standard deviations of 1.5 and $1.2 \%$ for the triplicate measurements of the samples indicate that some of the differences between $\delta D C^{29}$ and $C^{31}$ may be real. One may speculate that $\mathrm{C}^{29}$ and $\mathrm{C}^{31}$ derive proportionally from distinct plant species being to a greater or lesser extent sensitive to evaporative $\delta \mathrm{D}$ enrichment. However, for the purpose of this review, we will discuss primarily the broad, common patterns ('SD mean' in Fig. 14).

The first feature we would like to draw the attention to is the $\sim 10 \%$ o drop in $\delta \mathrm{D}$ from the Holocene $(\sim-200 \%)$ to the MIS2 loess V L1L1. As above, correction for the global ice volume effect would increase this difference, but still the difference is much less than what one would expect from a high to midlatitude temperature signal alone. For compa-rison, the $\delta \mathrm{D}$ record from Vostok, Antarctica, is plotted in Fig. 14. One possible explanation might be that the soil water was isotopically enriched during glacials due to more arid conditions (or more precisely a higher ratio of evaporation to precipitation). In fact, many oxygen records from the Mediterranean region, including e.g. the Soreq and Piqiin cave speleothems in Israel (BAR-MATTHEws et al. 2003) show more enriched values (Fig. 14), which was originally interpreted to document more arid conditions (RoBERTs et al. 2008). However, doubts concerning this interpretation arose from lake level reconstructions of Lake Lisan, a glacial freshwater lake occupying the Dead Sea region (LiskeR et al. 2009). As it turned out, the speleothem oxygen isotope records mainly followed the isotopic signal of the Mediterranean Sea, which serves as water source for regional precipitation and shows a pronounced enrichment during glacials (>3\%) (BAR-MATTHEws et al. 2003; AlMOGILABIN et al. 2009). This 'source effect' (translating into 25\%o glacial-interglacial difference in $\delta \mathrm{D}$ of regional precipitation) is likely responsible for off-setting the expected temperature signal at Crvenka at least to some degree. Additionally, past changes in atmospheric circulation patterns and thus changing moisture source areas might have affected our record, though this effect is difficult to quantify. 
It should be acknowledged at this point, that a detailed, robust deconvolution of all these factors is not trivial. Nevertheless, we would like to point to a second interesting feature of our record. The temperature difference between the Holocene and the Eemian basically accounts already for the differences in alkane $\delta \mathrm{D}$. This might indicate that the Mediterranean source water effect, from which one would infer more positive isotope values during the Holocene, was offset by other factors, for example differences in aridity. If correct, this might document that the Eemian was more arid than the Holocene, an interpretation that would be in good agreement with the alkane patterns that have been used (further above) to infer more grass vegetation (steppe) during the Eemian.

We summarize that $\delta D$ records from alkanes in LPS provide valuable information about past climatic and environmental changes, but that deconvolving the various factors influencing $\delta \mathrm{D}$ can be challenging. Apart from temperature, changes in precipitation, atmospheric circulation patterns and source effects should be taken into consideration.

\subsection{Compound-specific $\delta^{18} 0$-analyzes of monosaccharides}

Similar to deuterium, the ${ }^{18} \mathrm{O}$ concentration in precipitation depends on climatic factors and therefore has high potential as paleoclimate proxy in appropriate archives. Likewise, however, bulk soil or sediment isotope analyzes using TC/ EA-IRMS have the disadvantage that many different inorganic (carbonates, water from clay minerals) and organic pools contribute to the pyrolytically produced $\mathrm{CO}$, which hence represents a mixed signal (see Fig. 3). Furthermore, not all oxygen pools in soils have a climate signal incorporated, as for instance oxygen in lignin does not derive from water, but from the atmosphere (SснмIDT et al. 2001).

In loess research, attempts have been made to obtain $\delta^{18} \mathrm{O}$ records from pedogenetic carbonates, mollusc shells, and crystal water in clay minerals (KuLESHOV \& GAVRILOV 2001; Pustovoytov \& Terhorst 2004). However, in contrast to carbonates from stalagmites, it is much more difficult to get well dated and continuous records, with potential recrystal-

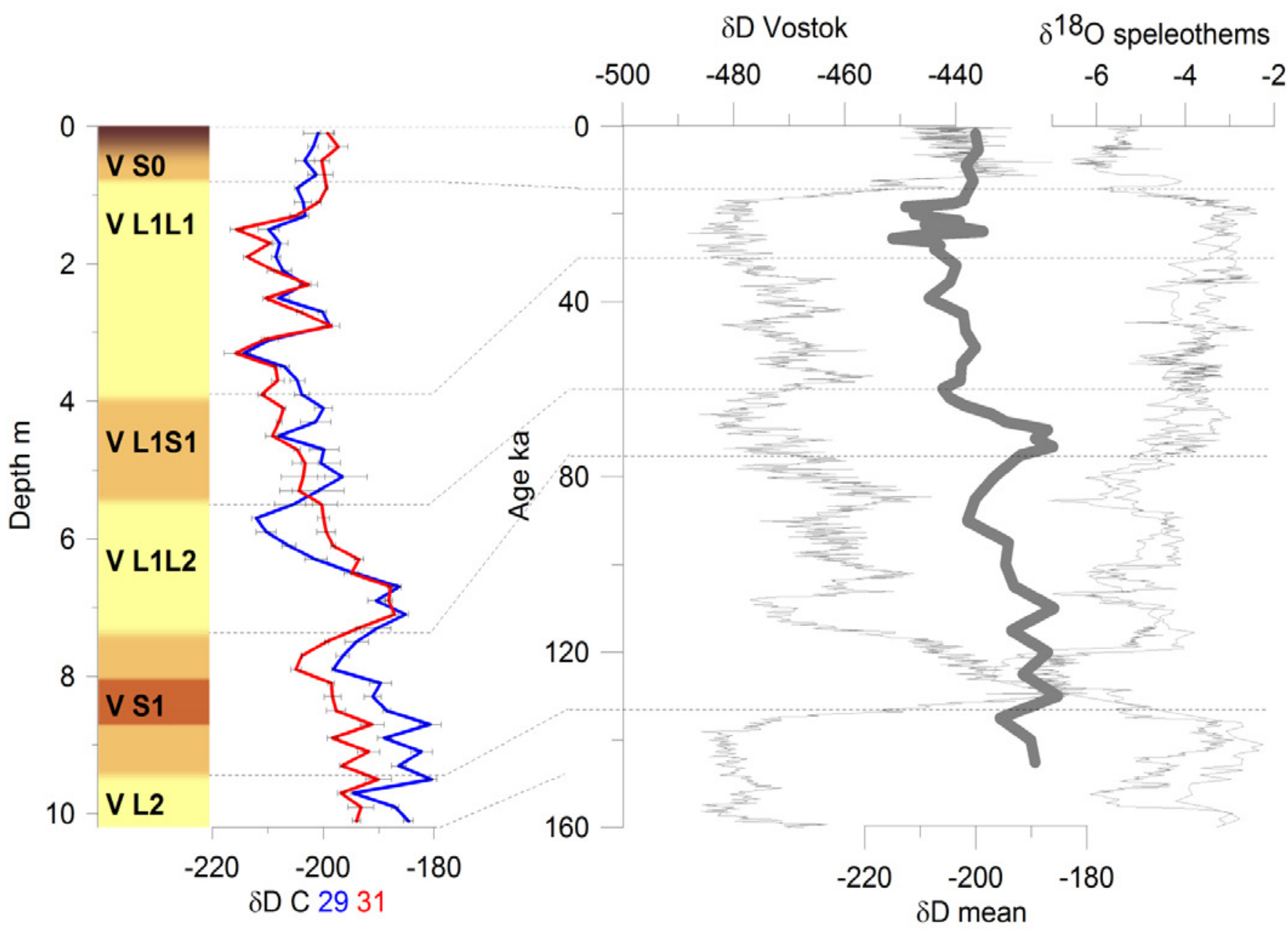

Fig. 14: Stratigraphy and $\delta D$ of $n C_{29}$ and $n C_{31}$ from the Crvenka profile, compared to the $\delta D$ record from Vostok and the $\delta^{18} O$ record from the Soreq/Piqiin speleothems (scaled to reflect respective $\delta D$ changes based on the meteoric water line). Many factors, such as temperature, changes in precipitation, atmospheric circulation patterns, source effects and evaporative isotopic enrichment, need to be considered for the interpretation of the LPS $\delta D$-values.

Abb. 14: Stratigraphie und $\delta D$-Werte der $n$-Alkane $n C_{29}$ und $n C_{31}$ der LPS Crvenka. Im Vergleich dazu die $\delta D$-Kurve des Vostok Eisbohrkerns und die $\delta^{18} O$ Kurve der Soreq/Piqiin Speläothemen (umgerechnet auf entsprechende $\delta D$-Werte anhand der Meteoric Mater Line). Zahlreiche Faktoren, z.B. Temperatur, Niederschlagsmenge, Veränderungen der atmoshärischen Zirkukation, Quell-Effekte und Isotopenanreicherung durch Verdunstung müssen bei der Interpretation der LPS $\delta$ D-Ergebnisse berücksichtigt werden. 
lisation presenting a major challenge. An alternative, more elegant approach might be to employ again compound-specific isotope methods (Fig. 15).

It is well known, for example, that hexoses (glucose, mannose and galactose), deoxyhexoses (fucose, rhamnose) and pentoses (xylose, arabinose) are plant and microbial biomarkers in soils (Gross \& Glaser 2004; SAUheItL et al. 2005; JIA et al. 2008). Plant-derived monosaccharides could thus be measured in soils and sediments via GC-Py-IRMS (Fig. 15). Although the instrumental coupling of GC-Py-IRMS is commercially available for about 10 years, this method has hardly been adopted by researches so far (HeNER et al. 1998; Jung et al. 2005; Jung et al. 2007; Greule et al. 2008). We think that the following $\delta^{18} \mathrm{O}$ method may be most promising for loess research in the near future. More details are described in ZECH \& GLASER (2009):

- hydrolytic extraction of cellulose- or hemicellulose-derived neutral sugars, such as glucose, xylose, arabinose, fucose and rhamnose from soils/sediments

- purification of the monosaccharides using XAD- (remo-val of organic contaminants) and Dowex- (cation exchange resins)-columns

- derivatization of the monosaccharides in order to make them GC-amenable

- GC-separation of the individual monosaccharide-derivatives

- 'online' pyrolysis of the GC-eluates and quantitative conversion into carbon monoxide

- 'online' $\delta^{18} \mathrm{O}$-determination for the $\mathrm{CO}$ in the IRMS.
As quality tests during the measurements, the authors recommend to regularly (i) co-analyze not only the masses $\mathrm{m} / \mathrm{z} 28$ and $30\left(\mathrm{C}^{16} \mathrm{O}\right.$ and $\mathrm{C}^{18} \mathrm{O}$, respectively), but also the masses $\mathrm{m} / \mathrm{z} 44$ and $46\left(\mathrm{C}^{16} \mathrm{O}_{2}\right.$ and $\left.\mathrm{C}^{16} \mathrm{O}^{18} \mathrm{O}\right)$ in order to minimize isotope fractionation effects due to not quantitative $\mathrm{CO}$-production (ii) co-analyze n-alkanes in order to check for oxygen contamination in the system, because alkanes contain no oxygen atoms and must not produce $\mathrm{CO}$ peaks in the chromatograms (iii) run batches of external monosaccharide standards with known $\delta^{18} \mathrm{O}$ signatures and varying concentrations in order to check for amount-effects of the $\delta^{18} \mathrm{O}$ measurements and to stick as close as possible to the 'Principle of Identical Treatment' of samples and standards. Of course, when interpreting $\delta^{18} \mathrm{O}$ records from LPS, one should keep in mind that the oxygen isotopic composition in plants (and preserved soil organic matter) does not only depend on $\delta^{18} \mathrm{O}$ in precipitation/soil water, but is similar to $\delta \mathrm{D}$ controlled by evaporative enrichment and biophysiological fractionations, too (SCHEIDEgGer et al. 2000; BARBOUR 2007; Cuntz et al. 2007). Nevertheless, our proposed method might provide valuable new proxies from LPS, which could be directly correlated with other $\delta^{18} \mathrm{O}$ records derived for instance from ice-cores, stalagmites or deep-sea sediments. Furthermore, the combination of $\delta \mathrm{D}$ - and $\delta^{18} \mathrm{O}$-analyzes might help to assess the deuterium excess from LPS records and thus help to deconvolve in future the varying factors influencing the isotopic records. ZECH \& GLASER (2009) highlight that the new $\delta^{18} \mathrm{O}$ method could potentially help to evaluate and improve paleolimnological and -climatic stud-
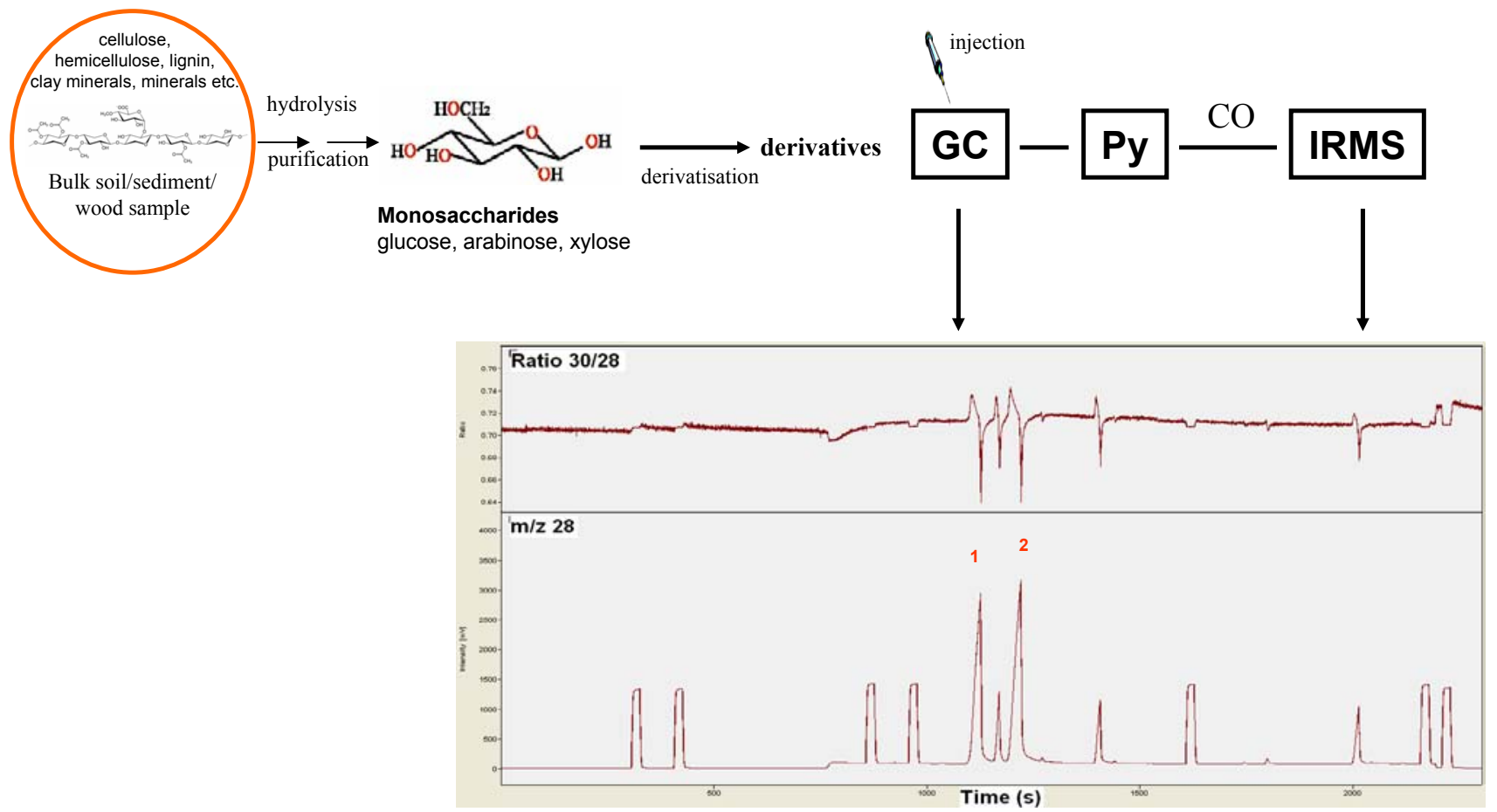

$(1,2)=$ plant-derived sugars arabinose (1) and xylose (2)

Fig. 15: Principle of compound-specific $\delta^{18} \mathrm{O}$ analyzes of plant-derived monosaccharides in soils. Monosaccharides are released hydrolytically from a soil/ sediment/wood sample and derivatised after purification. The sugar-derivatives eluting successively from the GC-column are converted online to carbon monoxide (CO) and the ${ }^{18} \mathrm{O} /{ }^{16} \mathrm{O}$ isotopic composition of the gas is measured via a coupled IRMS.

Abb. 15: Prinzip der substanz-spezifischen $\delta^{18} O$-Analytik pflanzenbürtiger Einzelzucker in Böden. Einzelzucker werden hydrolytisch aus Boden/Sediment/ Holz-Proben gewonnen und nach Aufreinigung derivatisiert. Die nacheinander von der GC-Säule eluierenden Zucker-Derivate werden im ,online 'Verfahren in Kohlenmonoxid-Gas (CO) umgewandelt und dessen ${ }^{18} \mathrm{O} /{ }^{16} \mathrm{O}$ Isotopenzusammensetzung in einem gekoppelten IRMS gemessen. 
ies targeting lake cellulose for $\delta^{18} \mathrm{O}$ analyzes (WoLfE et al. 2001; Wolfe et al. 2007; Wissel et al. 2008). Replacing the TC/EA-IRMS measurements on the extracted cellulose with GC-Py-IRMS measurements on the hydrolysed sugar monomers can overcome the common challenges of the current methods, namely purity after extraction and hygroscopicity of the cellulose.

Case study: Oxygen isotopic fractionation/exchange effects during litter decomposition?

In a first application of the above described method, ZECH et al. (2011) used 5 different litter species (maple, beech, ash, pine and spruce), which were degraded in a 27 months field litterbag experiment in order to evaluate isotopic de-gradation effects during litter decomposition. While the bulk $\delta^{18} \mathrm{O}$ values became systematically more negative due to relative mass increase of lignin (ranging from $145 \%$ in beech to $235 \%$ in pine litter) and relative mass decrease of (hemi-)cellulose (ranging from $31 \%$ in maple to $67 \%$ in ash), the compoundspecific $\delta^{18} \mathrm{O}$ values of the monosaccharides revealed no sys-

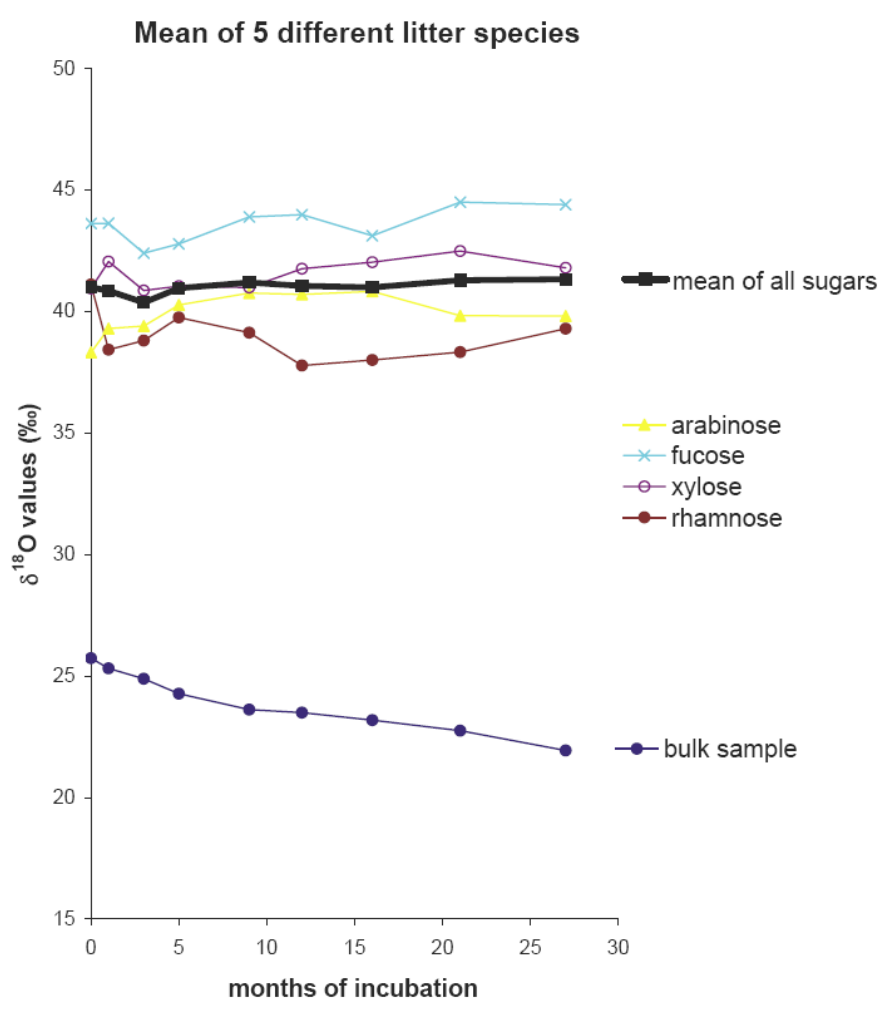

Fig. 16: Mean $\delta^{18} \mathrm{O}$ values for 5 litter species during degradation in a 27 months field litterbag experiment (from ZECH et al. 2011, submitted). While bulk litters are systematically depleted probably due to preferential degradation of cellulose (a relatively ${ }^{18} \mathrm{O}$ enriched organic pool) compared to lignin (a relatively ${ }^{18} \mathrm{O}$ depleted organic pool), $\delta^{18} \mathrm{O}$ values of hemicellulose sugars remain virtually unchanged. This finding corroborates that oxygen exchange reactions and isotopic fractionation processes do not affect the $\delta^{18} \mathrm{O}$ values of sedimentary sugar biomarkers.

Abb. 16: Gemittelte $\delta^{18} O$-Werte für 5 Streuproben eines 27-monatigen Freiland Streubeutel-Zersetzungs-Experiments (aus ZECH et al. 2011, submitted). Während die Gesamtstreu vermutlich aufgrund des präferenziellen Abbaus von Zellulose (relativ ${ }^{18} \mathrm{O}$-angereicherter organischer Pool) gegenüber bspw. Lignin (relativ ${ }^{18} \mathrm{O}$-abgereicherter organischer Pool) systematisch isotopisch abgereichert wird, bleiben die $\delta^{18} \mathrm{O}$-Werte der Hemizellulosen nahezu unverändert. Dieser Befund bestätigt, dass weder Sauerstoffaustausch-Reaktionen noch Isotopenfraktionierungsprozesse während der Degradation die $\delta^{18} \mathrm{O}$-Werte der Hemizellulose-Biomarker beeinträchtigen. tematic trend over time (Fig. 16). This corroborates the general notion that isotopic signals of individual compounds are only negligibly affected during mineralisation, and it also indicates that oxygen exchange reactions of the hydroxyloxygen atoms do not occur.

Having demonstrated the absence of degradation effects on the ${ }^{18} \mathrm{O}$-(hemi-) cellulose proxy, ongoing work focuses on (i) eliminating the oxygen atom in $\mathrm{C} 1$ position, which is prone to exchange reaction during analytical procedure and corrected mathematically, so far, (ii) calibrating the proxy with appropriate sample sets from climate chamber experiments and natural climate transects and on (iii) applying the proxy to promising LPS.

\section{Concluding remarks}

Given the meanwhile extremely wide range of very different analytical tools being employed in loess research, including numerical dating, micromorphology, mineralogy, elemental analysis, environmental and paleomagnetism, grain size analysis, and biomarker and isotope analyzes, we conclude that multi-disciplinary and multi-proxy approaches are most promising.

We hope that our review illustrated the fascinating potential of the selected novel methods in loess research, and also provided an overview over the current shortcomings and limitations. Ongoing joint research is required to further develop and apply the new methods.

\section{Acknowledgements}

The authors gratefully acknowledge the support provided by the many cooperation partners world-wide during the last few years. M. Zech and B. Buggle thank all members of the Soil Physics Department, University of Bayreuth, for the familial working atmosphere, A. Mergner and $\mathrm{K}$ Jeschke for laboratory assistance, PD Dr. M. Fuchs, Dr. U. Hambach and Dr. G. Wiesenberg for valuable discussions and Prof. B. Glaser, Prof. G. Gebauer, Prof. B. Huwe and Prof. S. Markovic for logistic support. B. Buggle appreciates the financial support given by the German Research Foundation (DFG GL 327/8-2) and M. Zech expresses gratitude for the financial support given by the Alexander von Humboldt-Foundation and the German Research Foundation (DFG ZE 844/1-1). R. Zech was supported by an SNF fellowship, and gratefully acknowledges the supervision and training by Prof. Y. Huang and his team at the Brown University over the last two years. We also thank Prof. M. Frechen for the editorial handling and proof-reading of our manuscript and an anonymous reviewer for valuable comments and suggestions.

\section{References}

Almogi-Labin, A., Bar-Matthews, M., Shriki, D., Kolosovsky, E., PAterne, M., Schilman, B., Ayalon, A., Aizenshtat, Z. \& Matthews, A. (2009): Climatic variability during the last $\sim 90 \mathrm{ka}$ of the southern and northern Levantine Basin as evident from marine records and speleothems. - Quaternary Science Reviews, 28(25-26): 2882-2896.

Amelung, W. \& Zhang, X. (2001): Determination of amino acid enantiomers in soils. - Soil Biology \& Biochemistry, 33: 553-562.

Amelung, W. \& Brodowski, S. (2002): In vitro quantification of hydrolysis-induced racemization of amino acid enantiomers in environmen- 
tal samples using deuterium labeling and electon impact ionization mass spectrometry. - Analytical Chemistry, 74: 3239-3246.

Amelung, W. (2003): Nitrogen biomarkers and their fate in soil. - Journal of Plant Nutrition and Soil Science, 166: 677-686.

Amelung, W., Brodowski, S., Sandhage-Hofmann, A. \& Bol, R. (2008): Combining Biomarker with Stable Isotope Analyses for Assessing the Transformation and Turnover of Soil Organic Matter. - In: D.L. Sparks (Editor), Advances in Agronomy. - Academic Press, Burlington, $155-250$.

Araguas-Araguas, L., Froenlich, K. ש Rozanski, K. (2000): Deuterium and oxygen-18 isotope composition of precipitation and atmospheric moisture. - Hydrological Processes, 14: 1341-1355.

BADA, J.L. (1985): Racemization of amino acids. - In: G.C. Barrett (Editor), Chemistry and Biochemistry of Amino Acids. - Chapman and Hall, London, New York, 399-414.

BAI, Y., FANG, X., NIE, J., WANG, Y. \& WU, F. (2009): A preliminary reconstruction of the paleoecological and paleoclimatic history of the Chinese Loess Plateau from the application of biomarkers. - Palaeogeography, Palaeoclimatology, Palaeoecology, 271: 161-169.

BALABANE, M. (1983): Oxygen-18, deuterium and carbon-13 content of organic matter from litter and humus layers in podzolic soils. - Catena, 10: 159-166.

Bar-Matthews, M., Ayalon, A., Gilmour, M., Matthews, A. ש HawkesworTH, C.J. (2003): Sea-land oxygen isotopic relationships from planktonic foraminifera and speleothems in the Eastern Mediterranean region and their implication for paleorainfall during interglacial intervals. - Geochimica et Cosmochimica Acta, 67(17): 3181-3199.

BARBour, M. (2007): Stable oxygen isotope composition of plant tissue: a review. - Functional Plant Biology, 34: 83-94.

Bechtel, A., Smittenberg, R.H., Bernasconi, S.M. \& Schubert, C.J. (2010): Distribution of branched and isoprenoid tetraether lipids in an oligotrophic and a eutrophic Swiss lake: Insights into sources and GDGT-based proxies. - Organic Geochemistry, 41(8): 822-832.

Blaga, C., Reichart, G.-J., Heiri, O. \& Sinninghe Damsté, J. (2009): Tetraether membrane lipid distributions in water-column particulate matter and sediments: a study of 47 European lakes along a northsouth transect. - Journal of Paleolimnology, 41(3): 523-540.

Bourbonniere, R.A., Telford, S.L., Ziolkowski, L.A., Lee, J., Evans, M.S. \& MEYERS, P.A. (1997): Biogeochemical marker profiles in cores of dated sediments from large North American lakes. - In: R.P. Eganhouse (Editor), Molecular Markers in Environmental Geochemistry, ACS Symposium Series. - American Chemical Society, Washington, DC, 133-150.

Boutton, T.W. (1996): Stable Carbon Isotope Ratios of Soil Organic Matter and Their Use as Indicators of Vegetation and Climate Change. - In: T.W. Boutton and S. Yamasaki (Editors), Mass Spectrometry of Soils. - Marcel Dekker, Inc., New York, 47-82

Buggle, B., Wiesenberg, G. \& Glaser, B. (2010): Is there a possibility to correct fossil n-alkane data for postsedimentary alteration effects? Applied Geochemistry, 25(7): 947-957.

Burgoyne, T. \& Hayes, J.M. (1998): Quantitative production of H2 by pyrolysis of gas chromatographic effluents. - Analytical Chemistry, 70: 5136-5141.

Craig, H. (1961): Isotopic variations in meteoric waters. - Science, 133: 1702-1703.

Cranwell, P.A. (1973): Chain-length distribution of n-alkanes from lake sediments in relation to post-glacial environmental change. - Freshwater Biology, 3: 259-265.

Cranwell, P.A. (1981): Diagenesis of free and bound lipids in terrestrial detritus deposits in a lacustrine sediment. - Organic Geochemistry, 3: 79-89.

Cuntz, M., Ogée, J., Farquhar, G., Peylin, P. \& Cernusak, L. (2007): Modelling advection and diffusion of water isotopologues in leaves. Plant, Cell and Environment, 30: 892-909.

Danis, P.A., Masson-Delmotte, V., Stievenard, M., Guillemin, M.T., Daux, V., Naveau, P. \& von Grafenstein, U. (2006): Reconstruction of past precipitation $\delta^{18} \mathrm{O}$ using tree-ring cellulose $\delta^{18} \mathrm{O}$ and $\delta^{13} \mathrm{C}$ : a calibration study near Lac d'Annecy, France. - Earth and Planetary Science Letters, 243: 439-448.

DANSGAARD, P. (1964): Stable isotopes in precipitation. - Tellus, 16: 436-468.

Dawson, D., Grice, K., Alexander, R. \& Edwards, D. (2007): The effect of source and maturity on the stable isotopic compositions of individual hydrocarbons in sediments and crude oils from the Vulcan Sub-basin, Timor Sea, Northern Australia. - Organic Geochemistry, 38: $1015-1038$
Eganhouse, R.P. (Editor), (1997): Molecular Markers in Environmental Geochemistry. - ACS Symposium Series 671, Washington, DC.

Eglington, G. \& Hamilton, R. (1967): Leaf epicuticular waxes. - Science, 156: $1322-1334$.

EgLinton, T. \& Eglinton, G. (2008): Molecular proxies for paleoclimatology. - Earth and Planetary Science Letters, 275: 1-16.

Feakins, S. \& Sessions, A. (2010): Controls on the D/H ratios of plant leaf waxes in an arid ecosystem. - Geochimica et Cosmochimica Acta, 74: 2128-2141.

Ficken, K.J., Li, B., Swain, D.L. \& Eglinton, G. (2000): An n-alkane proxy for the sedimentary input of submerged/floating freshwater aquatic macrophytes. - Organic Geochemistry, 31: 745-749.

FRECHEN, M. (2011): Loess in Eurasia. - Quaternary International, 234.

GAT, J.R. (1996): Oxygen and hydrogen isotopes in the hydrologic cycle. Annual review of Earth and Planetary Sciences, 24: 225-262.

Gessler, A., Brandes, E., Buchmann, N., Helle, G., Rennenberg, H. \& BARNARD, R. (2009): Tracing carbon and oxygen isotope signals from newly assimilated sugars in the leaves to the tree-ring archive. Plant, Cell and Environment, 32(7): 780-795.

Glaser, B. (2005): Compound-specific stable-isotope $\left(\delta^{13} \mathrm{C}\right)$ analysis in soi science. - Journal of Plant Nutrition and Soil Science, 168: 633-648.

Glaser, B. \& ZECH, W. (2005): Reconstruction of climate and landscape changes in a high mountain lake catchment in the Gorkha Himal, Nepal during the Late Glacial and Holocene as deduced from radiocarbon and compound-specific stable isotope analysis of terrestrial, aquatic and microbial biomarkers. - Organic Geochemistry, 36: 1086-1098.

Gocke, M., Kuzyakov, Y. \& Wiesenberg, G. (2010): Rhizoliths in loess evidence for post-sedimentary incorporation of root-derived organic matter in terrestrial sediments as assessed from molecular proxies. Organic Geochemistry, 41: 1198-1206.

Greule, M., Hänsel, C., Bauermann, U. \& Mosandl, A. (2008): Feed additives: authenticity assessment using multicomponent-/multielement-isotope ratio mass spectrometry. - European Food Research and Technology, 227: 767-776.

GRoss, S. ש GLASER, B. (2004): Minimization of carbon addition during derivatization of monosaccharides for compound-specific $\delta^{13} \mathrm{C}$ analysis in environmental research. - Rapid Communications in Mass Spectrometry, 18: 2753-2764.

Hener, U., Brand, W.A., Hilkert, A.W., Juchelka, D., Mosandl, A. \& Podebrad, F. (1998): Simultaneous on-line analysis of ${ }^{18} \mathrm{O} /{ }^{16} \mathrm{O}$ and $13 \mathrm{C} / 12 \mathrm{C}$ ratios of organic compounds using GC-pyrolysis-IRMS. Zeitschrift für Lebensmitteluntersuchung und -Forschung A, 206(3): $230-232$.

Hilkert, A., Douthitt, C., Schlüter, H. \& Brand, W. (1999): Isotope ratio monitoring gas chromatography/mass spectrometry of $\mathrm{D} / \mathrm{H}$ by high temperature conversion isotope ratio mass spectrometry. - Rapid Communications in Mass Spectrometry, 13: 1226-1230.

Hou, J., D’Andrea, W., MacDonald, D. \& Huang, Y. (2007): Hydrogen isotopic variability in leaf waxes among terrestrial and aquatic plants around Blood Pond, Massachusetts (USA). - Organic Geochemistry, 38: 977-984.

Huang, Y., Shuman, B., Wang, Y. \& Webb III, T. (2004): Hydrogen isotope ratios of individual lipids in lake sediments as novel tracers of climatic and environmental change: a surface sediment test. - Journal of Paleolimnology, 31: 363-375.

Jia, G., Dungait, J.A.J., Bingham, E.M., Valiranta, M., Korhola, A. EVERSHED, R.P. (2008): Neutral monosaccharides as biomarker proxies for bog-forming plants for application to palaeovegetation reconstruction in ombrotrophic peat deposits. - Organic Geochemistry, 39: 1790-1799.

Jung, J., Sewenig, S., Hener, U. \& Mosandl, A. (2005): Comprehensive authenticity assessment of lavender oils using multielement/multicomponent isotope ratio mass spectrometry analysis and enantioselective multidimensional gas chromatography-mass spectrometry. European Food Research and Technology, 220: 232-237.

Jung, J., Puff, B., Eberts, T., Hener, U. \& Mosandl, A. (2007): Reductive ester cleavage of acyl glycerides-GC-C/P-IRMS measurements of glycerol and fatty alcohols. - European Food Research and Technology, 225: 191-197.

Kaufman, D. (2003): Amino acid paleothermometry of Quaternary ostracodes from the Bonneville Basin, Utah. - Quaternary Science Reviews, 22(8-9): 899-914.

Kim, J.-H., Schouten, S., Hopmans, E.C., Donner, B. \& Sinninghe DamSTÉ, J.S. (2008): Global sediment core-top calibration of the TEX86 
paleothermometer in the ocean. - Geochimica et Cosmochimica Acta, 72(4): 1154-1173.

Kolattukudy, P.E. (1976): Biochemistry of plant waxes. - In: P.E. KolatTUKUDy (Editor), Chemistry and Biochemistry of Natural Waxes. - Elsevier, Amsterdam, 290-349.

Kornexl, B.E., Gehre, M., Höfling, R. \& Werner, R.A. (1999): On-line d18O Measurement of Organic and Inorganic Substances. - Rapid Communications in Mass Spectrometry, 13: 1685-1693.

Kuleshov, V. \& Gavrilov, Y. (2001): Isotopic composition (d13C, d18O) of carbonate concretions from terrigenous deposits in the Northern Caucasus. - Lithology and Mineral Resources, 36: 160-163.

Lichtfouse, E. (1998): Isotope and Biosynthetic Evidence for the Origin of Long-Chain Aliphatic Lipids in Soils. - Naturwissenschaften, 85: 76-77.

Lichtfouse, E., Chenu, C., Baudin, F., Leblond, C., Silva, M., Behar, F., Derenne, S., Largeau, C., Wehrung, P. \& Albrecht, P. (1998): A novel pathway of soil organic matter formation by selective preservation of resistant straight-chain biopolymers: chemical and isotope evidence. - Organic Geochemistry, 28(6): 411-415.

Lisker, S., Vaks, A., Bar-Matthews, M., Porat, R. \& Frumkin, A. (2009): Stromatolites in caves of the Dead Sea Fault Escarpment: implications to latest Pleistocene lake levels and tectonic subsidence. - Quaternary Science Reviews, 28(1-2): 80-92.

Liu, T., Ding, Z. ひ RUTter, N.W. (1999): Comparison of Milankovitch periods between continental loess and deep sea records over the last 2.5 Ma. - Quaternary Science Reviews, 18: 1205-1212.

LiU, W. \& HuANG, Y. (2005): Compound specific D/H ratios and molecular distributions of higher plant leaf waxes as novel paleoenvironmental indicators in the Chinese Loess Plateau. - Organic Geochemistry, 36: 851-860.

Liu, W., Huang, Y., An, Z., Clemens, S.C., Li, L., Prell, W.L. \& Ning, Y. (2005): Summer monsoon intensity controls $\mathrm{C} 4 / \mathrm{C} 3$ plant abundance during the last $35 \mathrm{ka}$ in the Chinese Loess Plateau: Carbon isotope evidence from bulk organic matter and individual leaf waxes. - Palaeogeography, Palaeoclimatology, Palaeoecology, 220: 243-254.

LIU, W., YANG, H. \& LI, L. (2006): Hydrogen isotopic compositions of n-alkanes from terrestrial plants correlate with their ecological life forms. - Oecologia, 150: 330-338.

MAHANey, W.C. $\circlearrowright$ RUtTeR, N.W. (1989): Amino acid D/L ratio distribution in two Late Quaternary soils in the afroalpine zone of Mount Kenya, East Africa. - Catena, 16: 205-214.

Markovic, S., Smalley, I., Hambach, U. \& Antoine, P. (2009): Loess in the Danube region and surrounding loess provinces: The Marsigli memorial volume. - Quaternary International, 198(1-2): 5-6.

MARKovic, S. (2011): Loessfest 2. - special issue in QI, in press.

MAYER, B. ש SCHWARK, L. (1999): A 15,000-year stable isotope record from sediments of Lake Steisslingen, Southwest Germany. - Chemical Geology, 161: 315-337.

Mügler, I., Sachse, D., Werner, M., Xu, B., Wu, G., Yao, T. \& Gleixner, G. (2008): Effect of lake evaporation on $\mathrm{dD}$ values of lacustrine n-alkanes: A comparison of Nam Co (Tibetian Plateau) and Holzmaar (Germany). - Organic Geochemistry, 39: 711-729.

Novothny, A., Frechen, M., Horváth, E., BradÁk, B., Oches, E., McCoy, W. \& STEvens, T. (2009): Luminescence and amino acid racemization chronology of the loess-paleosol sequence at Süttő, Hungary. - Quaternary International, 198(1-2): 62-76.

Oches, E. \& McCoy, W. (2001): Historical developments and recent advances in amino acid geochronology applied to loess research: examples from North America, Europe, and China. - Earth-Science Reviews, 54(1-3): 173-192.

Pagani, M., Pedentchouk, N., Huber, M., Sluijs, A., Schouten, S. Brinkhuis, H., Damste, J.S.S., Dickens, G. \& ExPEdition 302 SCienTISTS (2006): Arctic hydrology during global warming at the Palaeocene/Eocene thermal maximum. - Nature, 442: 671-675.

Pedentchouk, N., Freeman, K.H. \& Harris, N. (2006): Different response of $\mathrm{dD}$ values of $\mathrm{n}$-alkanes, isoprenoids, and kerogen during thermal maturation. - Geochimica et Cosmochimica Acta, 70: 2063-2072.

Penkman, K., Kaufman, D. \& Collins, M. (2008): Closed-system behaviour of the intra-crystalline fraction of amino acids in mollusc shells. - Quaternary Geochronology, 3(1-2): 2-25.

Peterse, F., Kim, J.-H., Schouten, S., Kristensen, D.K., Koç, N. \& SinNINGHE DAMSTÉ, J.S. (2009a): Constraints on the application of the MBT/CBT palaeothermometer at high latitude environments (Svalbard, Norway). - Organic Geochemistry, 40(6): 692-699.

Peterse, F., Meer, M.T.J. v.D., Schouten, S., Jia, G., OssebaAr, J., Blokker, J. \& DAmste, J.S.S. (2009b): Assessment of soil n-alkane $\delta \mathrm{D}$ and branched tetraether membrane lipid distributions as tools for paleoelevation reconstruction. - Biogeosciences, 6: 2799-2807.

Powers, L., Werne, J.P., Vanderwoude, A.J., Sinninghe Damsté, J.S. Hopmans, E.C. \& Schouten, S. (2010): Applicability and calibration of the TEX86 paleothermometer in lakes. - Organic Geochemistry, 41(4): 404-413.

Prügel, B., Loosveldt, P. \& Garrec, J.P. (1994): Changes in the content and constituents of the cuticular wax of Picea abies (L.) Karst. in relation to needle ageing and tree decline in five European forest ageas. - Trees, 9: 80-87.

Pustovoytov, K. \& Terhorst, B. (2004): Linking stable oxygen and carbon isotopes with stomatal conductance and photosynthetic capacity: a conceptual model. - Revista Mexicana de Ciencias Geológicas, 21(1): 88-93.

Roberts, N., Jones, M.D., Benkaddour, A., Eastwood, W.J., Filippi, M.L., Frogley, M.R., Lamb, H.F., Leng, M.J., Reed, J.M., Stein, M., Stevens, L., VAlero-GarcÉs, B. \& Zanchetta, G. (2008): Stable isotope records of Late Quaternary climate and hydrology from Mediterranean lakes: the ISOMED synthesis. - Quaternary Science Reviews, 27: 2426-2441.

RudNeR, Z. \& SÜMEgI, P. (2001): Recurring Taiga forest-steppe habitats in the Carpathian Basin in the Upper Weichselian. - Quaternary International, 76/77: 177-189.

Ruppenthal, M., Oelmann, Y. ¿ Wilcke, W. (2010): Isotope ratios of nonexchangeable hydrogen in soils from different climate zones. - Geoderma, 155: 231-241.

SACHSE, D., RADKE, J. \& GleixNER, G. (2004): Hydrogen isotope ratios of recent lacustrine sedimentary n-alkanes record modern climate variability. - Geochimical et Cosmochimica Acta, 68(23): 4877-4889.

Sauer, P.E., Eglinton, T., Hayes, J.M., Schimmelmann, A. \& Sessions, A. (2001): Compound-specific D/H ratios of lipid biomarkers from sediments as a proxy for environmental and climatic conditions. - Geochimica et Cosmochimica Acta, 65(2): 213-222.

SAUHeitr, L., Glaser, B. \& Bol, R.A. (2005): Short-term dynamics of slurryderived plant and microbial sugars in a temperate grassland soil as assessed by compound-specific $\delta^{13} \mathrm{C}$ analyses. - Rapid Communications in Mass Spectrometry, 19: 1437-1446.

Schatz, A., Zech, M., Buggle, B., Gulyas, S., Hambach, U., Markovic, S., SüMEgI, P. \& Scholten, T. (2011): The Quaternary loess record of Tokaj, Hungary - reconstructing palaeoenvironment, vegetation and climate using stable $\mathrm{C}$ and $\mathrm{N}$ isotopes and biomarkers. - Quaternary International, doi:10.1016/j.quaint.2010.10.009.

SCheidegger, Y., SAurer, M., BAHN, M. \& Siegwolf, R. (2000): Linking stable oxygen and carbon isotopes with stomatal conductance and photosynthetic capacity: a conceptual model. - Oecologia, 125: 350-357.

Schimmelmann, A., Sessions, A. \& Mastalerz, M. (2006): Hydrogen isotopic $(\mathrm{D} / \mathrm{H})$ composition of organic matter during diagenesis and thermal maturation. - Annual Review of Earth and Planetary Sciences, 34: 501-533.

Schmidt, H.-L., Werner, R. \& Rossmann, A. (2001): ${ }^{18} \mathrm{O}$ Pattern and biosynthesis in natural plant products. - Phytochemistry, 58: 9-32.

Schouten, S., Hopmans, E., Schefuss, E. ¿ Sinninghe Damsté, J. (2002): Distributional variations in marine crenarchaeotal membrane lipids: a new tool for reconstructing ancient sea water temperatures? - Earth and Planetary Science Letters, 204: 265-274

SChWARK, L., Zink, K. \& LeChTENBECK, J. (2002): Reconstruction of postglacial to early Holocene vegetation history in terrestrial Central Europe via cuticular lipid biomarkers and pollen records from lake sediments. - Geology, 30(5): 463-466.

Sessions, A., Burgoyne, T., Schimmelmann, A. \& Hayes, J.M. (1999): Fractionation of hydrogen isotopes in lipid biosynthesis. - Organic Geochemistry, 30: 1193-1200.

Sessions, A., Sylva, S., Summons, R.E. \& Hayes, J.M. (2004): Isotopic exchange of carbon-bound hydrogen over geologic timescales. - Geochimica et Cosmochimica Acta, 68(7): 1545-1559.

SHEPHERD, T. \& GRIFFiths, D.W. (2006): The effects of stress on plant cuticular waxes. - New Phytologist, 171: 469-499.

SMith, F. \& FrEEMAN, K.H. (2006): Influence of physiology and climate on $\mathrm{dD}$ of leaf wax n-alkanes from $\mathrm{C} 3$ and $\mathrm{C} 4$ grasses. - Geochimica et Cosmochimica Acta, 70: 1172-1187.

STERNBERG, L. (1988): D/H Ratios of environmental water recorded by D/H ratios of plant lipids. - Nature, 333: 59-61.

Tierney, J.E., Russell, J.M., Eggermont, H., Hopmans, E.C., Verschuren, D. ¿ Sinninghe DAMSTÉ, J.S. (2010): Environmental controls on branched tetraether lipid distributions in tropical East African lake sediments. - Geochimica et Cosmochimica Acta, 74(17): 4902-4918. 
Wagner, G.A. (1998): Racemization. - In: G.A. Wagner (Editor), Age determination of young rocks and artifacts. - Springer, Berlin, 339-355.

Wang, X., Auler, A.S., Edwards, R.L., Cheng, H., Ito, E. \& Solheid, M. (2006): Interhemispheric anti-phasing of rainfall during the last glacial period. - Quaternary Science Reviews, 25(23-24): 3391-3403.

Weijers, J.W.H., Schouten, S., Donker, J.C.v.D., Hopmans, E.C. \& DAMSTE, J.S.S. (2007): Environmental controls on bacterial tetraether membrane lipid distribution in soils. - Geochimica et Cosmochimica Acta, 71: 703-713.

Weijers, J.W.H., Wiesenberg, G.L.B., Bol, R., Hopmans, E.C. \& Pancost, R.D. (2010): Carbon isotopic composition of branched tetraether membrane lipids in soils suggest a rapid turnover and a heterotrophic life style of their source organism(s). - Biogeosciences, 7: 2959-2973.

Werner, R.A., Kornexl, B.E., Rossmann, A. \& Schmidt, H.-L. (1996): Online determination of $\delta^{18} \mathrm{O}$ values of organic substances. - Analytica Chimica Acta, 319: 159-164.

Werner, R.A. (2003): The online ${ }^{18} \mathrm{O} /{ }^{16} \mathrm{O}$ analysis: development and application. - Isotopes in Environmental and Health Studies, 39(2): 85-104.

Wiesenberg, G.L.B., SchWARK, L. \& Schmidt, M.W.I. (2004): Improved automated extraction and separation procedure for soil lipid analyses. - European Journal of Soil Science, 55: 349-356.

Willis, K., Rudner, E. \& SüMEgi, P. (2000): The Full-Glacial Forests of Central and Southeastern Europe. - Quaternary Research, 53: 203-213.

Willis, K. \& ANDEL, T. (2004): Trees or no trees? The environments of central and eastern Europe during the Last Glaciation. - Quaternary Science Reviews, 23: 2369-2387.

Wissel, H., MAYr, C. \& Lücke, A. (2008): A new approach for the isolation of cellulose from aquatic plant tissue and freshwater sediments for stable isotope analysis. - Organic Geochemistry, 39: 1545-1561.

Wolfe, B.B., Edwards, T.W.D., Elgood, R.J. \& Beuning, K.R.M. (2001): Carbon and Oxygen Isotope Analysis of Lake Sediment Cellulose: Methods and Applications. - In: W.M. Last and J.P. Smol (Editors), Tracking Environmental Change Using Lake Sediments, 2, Physical and Chemical Techniques. - Kluwer Academic Publishers, Dordrecht, The Netherlands, 1-28.

Wolfe, B.B., Falcone, M., Clogg-Wright, K., Mongeon, C., Yi, Y., Brock, B., Amour, N., Mark, W. \& Edwards, T.W.D. (2007): Progress in isotope paleohydrology using lake sediment cellulose. - Journal of Paleolimnology, 37: 221-231.

Xie, S., Nott, C.J., Avsejs, L.A., Maddy, D., Chambers, F.M. \& Evershed, R.P. (2004): Molocular and isotopic stratigraphy in an ombotrophic mire for paleoclimate reconstruction. - Geochimical et Cosmochimica Acta, 68(13): 2849-2862.

Zech, M. (2006): Evidence for Late Pleistocene climate changes from buried soils on the southern slopes of Mt. Kilimanjaro, Tanzania. - Palaeogeography, Palaeoclimatology, Palaeoecology, 242: 303-312.

ZECH, M., ZECH, R. \& GlASER, B. (2007): A 240,000-year stable carbon and nitrogen isotope record from a loess-like palaeosol sequence in the Tumara Valley, Northeast Siberia. - Chemical Geology, 242: 307-318.

Zech, M., Buggle, B., Markovic, S., Lucic, T., Stevens, T., Gaudenyi, T., Jovanovic, M., Huwe, B. \& Zöller, L. (2008a): First Alkane Biomarker Results for the Reconstruction of the Vegetation History of the
Carpathian Basin (SE Europe). - In: J. Reitner, M. Fiebig, C. Neugebauer-Maresch, M. Pacher and V. Winiwarter (Editors), Veränderter Lebensraum - Gestern, Heute und Morgen, DEUQUA Symposium 2008. Abhandlungen der Geologischen Bundesanstalt 62, Wien, pp. 123-127.

ZECH, M. \& GLASER, B. (2008): Improved compound-specific $\delta^{13} \mathrm{C}$ analysis of n-alkanes for application in palaeoenvironmental studies. - Rapid Communications in Mass Spectrometry, 22: 135-142.

Zech, M., Zech, R., Zech, W., Glaser, B., Brodowski, S. \& Amelung, W. (2008b): Characterisation and palaeoclimate of a loess-like permafrost palaeosol sequence in NE Siberia. - Geoderma, 143(3-4): 281-295.

Zech, M., Buggle, B., Leiber, K., Markovic, S., Glaser, B., Нambach, U., Huwe, B., Stevens, T., Sümegi, P., Wiesenberg, G. \& Zöller, L. (2009a): Reconstructing Quaternary vegetation history in the Carpathian Basin, SE Europe, using n-alkane biomarkers as molecular fossils: problems and possible solutions, potential and limitations. -Eiszeitalter und Gegenwart - Quaternary Science Journal, 85(2): 150-157.

ZeCH, M. \& GLASER, B. (2009): Compound-specific $\delta^{18} \mathrm{O}$ analyses of neutral sugars in soils using GC-Py-IRMS: problems, possible solutions and a first application. - Rapid Communications in Mass Spectrometry, 23: 3522-3532.

Zech, M., Zech, R., Morrás, H., Moretti, L., Glaser, B. \& Zech, W. (2009b): Late Quaternary environmental changes in Misiones, subtropical NE Argentina, deduced from multi-proxy geochemical analyses in a palaeosol-sediment sequence. - Quaternary International, 196: 121-136.

Zech, M., Andreev, A., Zech, R., Müller, S., Hambach, U., Frechen, M. \& ZECH, W. (2010a): Quaternary vegetation changes derived from a loess-like permafrost palaeosol sequence in northeast Siberia using alkane biomarker and pollen analyses. - Boreas, 39: 540-550.

Zech, M., Werner, R., Juchelka, D., Buggle, B. \& Glaser, B. (2011): Absence of oxygen isotope fractionation/exchange of (hemi-) cellulosederived sugars during litter decomposition. - Organic Geochemistry, submitted.

Zech, R., Huang, Y., Zech, M., Tarozo, R. \& Zech, W. (2010b): A permafrost glacial hypothesis to explain atmospheric $\mathrm{CO} 2$ and the ice ages during the Pleistocene. - Cimate of the Past Discussions, 6: 2199-2221.

Zhang, Z., Zhao, M., Eglington, G., Lu, H. \& Huang, C. (2006): Leaf wax lipids as paleovegetational and paleoenvironmental proxies for the Chinese Loess Plateau over the last 170 kyr. - Quaternary Science Reviews, 20: 575-594.

ZÖller, L., Oches, E. ひ McCoy, W. (1994): Towards a revised chronostratigraphy of loess in Austria with respect to key sections in the Czech Republic and in Hungary. - Quaternary Science Reviews, 13(5-7): 465-472.

ZÖLlER, L. \& FAUST, D. (2009): Lower latitudes loess - Dust transport past and present. - Quaternary International, 196(1-3).

ZöLLER, L. (2010): New approaches to European loess: a stratigraphic and methodical review of the past decade. - Central European Journal of Geosciences, 2(1): 19-31. 